外科系専門医制度の行方：日本専門医

機構の取り組み

東京大学肝胆膵外科、人工臟器移植外

科

國土典宏

日本専門医機構は平成 29 年 6 月に理事

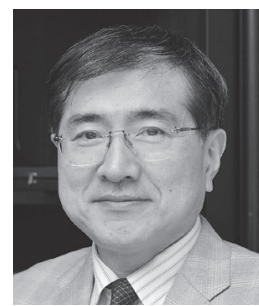
を改選し、新たな理事長として吉村博邦

氏を選出して新たな一歩を踏み出した。新執行部のキーワードは透明 性、柔軟性、ガバナンス強化であり、より良い新専門医制度を作り上 げるためにオールジャパンの体制で臨んでいる。新理事会は熟虑の末、 開始を一年延期することを決定したが、今後はできるだけ早期に新制 度が開始できるよう方針を定め、広報することが喫緊の課題であり、 基本問題検討委員会を新たに立ち上げ、理事会と社員学会との意志疎 通をはかっている。機構の基本方針として「小さな政府」をめざし、 専門医プログラムの整備や更新、認定業務の主体を各専門領域学会に ゆだね、機構はチェック機能、調整機能を果たして制度の標準化をは かることに主眼をおくことになった。医師の地域偏在是正を新専門医 制度によって行うことは、制度本来の目的ではないとしつつも、新制 度によって少なくとも偏在をさらに助長することがないような配慮が 必要であるということも理事会の共通認識となっている。そのために 「専門医研修プログラムと地域医療にかかわる新たな検討委員会」を 立ち上げ検討を開始した。新しい専門医制度の恩恵を受けるべき第 一は患者・国民であるが、実際に研修する若い専攻医のためになる制 度であることも重要である。特に外科系専門医取得が将来のインセン ティブにつながるような制度設計もこれから提案していきたいと考え ている。

〈略歴〉

西暦1956年（昭和 31 年） 6 月 5 日生

\begin{tabular}{|c|c|}
\hline 1981.3 & 東京大学医学部卒業 \\
\hline 1981.6- & 東京大学医学部附属病院第二外科 研修医 \\
\hline $1988.1-$ & 東京大学医学部附属病院第二外科 \\
\hline 1989.8-1991.7 & 米国ミシガン大学外科留学 \\
\hline $1995.3^{-}$ & 癌研究会附属病院外科 医員 \\
\hline 2001.1- & 癌研究会附属病院消化器外科＼cjkstart医長 \\
\hline 2001.4- & $\begin{array}{l}\text { 東京大学大学院医学系研究科外科学専攻臟器病態外科 } \\
\text { 膵外科 助教授 }\end{array}$ \\
\hline 2007.12- & 同肝胆膵外科、人工臟器 - 移植外科教授、臟器移植医 \\
\hline 2008.4- & 同外来化学療法部部長兼任、2015.4- 東京大学研究 \\
\hline
\end{tabular}

〈専攻分野〉

現在に至る

肝胆膵悪性腫瘍（特に肝細胞癌、転移性肝癌、胆道癌）の外科治療 肝移植、門脈圧穴進症

〈学会役員など〉

日本外科学会次期会頭 (前理事長)、日本医学会連合理事(財務委員長)、 日本移植学会理事・倫理委員長、日本肝胆膵外科学会理事・高度技能 医制度技術認定委員長、日本消化器外科学会評議員 - 学術委員会委員、 日本肝臓学会評議員・肝癌診療ガイドライン第 3 版・第 4 版改訂委員 長、学術集会審議委員会委員、日本臨床外科学会常任幹事・編集委員、 日本門脈圧方進症学会理事・編集委員、日本消化器病学会財団評議員、 日本外科感染症学会評議員、日本成人病（生活習慣病）学会評議員、 日本肝癌研究会会長・取扱い規約委員長、日本肝移植研究会常任世話 人、肝臟内視鏡外科研究会常任世話人、肝癌治療シミュレーション研 究会副代表幹事、臨床解剖研究会世話人、ICG 蛍光 Navigation Surgery研究会世話人

Fellow of American College of Surgeons

Fellow of Royal College of Surgeons of England

International Hepato-Pancreato-Biliary Association (IHPBA: Secretary General)

Asian-Pacific Hepato-Pancreato-Biliary Association (A-PHPBA: President)

International Liver Cancer Association (ILCA: Governing board member)

Honorary Regional Editor: HPB

Associate Editor: Liver Cancer, Japanese Journal of Clinical Oncology

Editorial Board Member: Annals of Surgery, Surgery, World Journal of Surgery, Journal of HPB Science 


\section{総会特別企画 $01-1$}

外科系専門医制度の行方一これからの 若手育成を考える一地方の方策は?

鹿児島大学消化器 · 乳腺甲状腺外 科1), 鹿児島大学心臓血管・消化器外 科学2), 鹿児島大学呼吸器外科学 ${ }^{3)}$, 鹿児島大学小児外科学 ${ }^{4}$

夏越眻次 ${ }^{1)}$, 井本浩 ${ }^{2}$, 佐藤雅美 ${ }^{3}$,

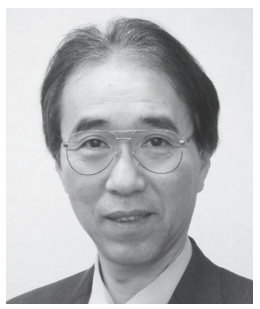

家入里志 ${ }^{4)}$, 飯野聡 ${ }^{1}$, 有上貴明 ${ }^{1)}$, 荒田憲一 ${ }^{2)}$, 北薗嚴 ${ }^{2}$,

大塚綱志 ${ }^{3)}$, 青木雅也 ${ }^{3)}$, 川野孝文 ${ }^{4)}$, 山田和歌 ${ }^{4)}$

新臨床研修医制度により，地方に残る研修医が激減し，さらに外科離 れが起こり，地方外科医療は危急存亡の秋を迎えているといっても過 言ではない，鹿児島県も研修医不足で，大学外科の入局者数も漸隇状 態で推移している. 県内病院の多くは大学関連病院であり, 離島・僻 地を含めた外科医療を担っている。外科専門医制度が混沌とした情勢 の中，若手外科医の增加と地方独自の外科教育の方策に関する現在ま での取組みを紹介する１）鹿児島大学の外科は 4 科から構成され ているが 窮地を乗り越えるために各科が協力体制で臨む必要があり 新専門医制度を引き金として, 外科全体で研修プログラム, カリキュ ラムを作成した。2 ）推薦された各教室の代表者によるワーキンク グループが結成され，新専門医制度に関する議論を行っている．特に 都会と比べ地方出張病院は症例数に偏りがあるため, 若手外科医の症 例確保を検討している, 各関連病院のNCDに登録された症例数なと のアンケート調查を行い, 専門医取得に関する症例数や手術内容を解 析した. 3) 鹿児島県で基幹病院となるのは大学病院がある. 多く の関連病院を含め, 基本的には大学病院を中心とした 1 県 1 プログラ ムを推奨することで進めている，来年より新プログラムも導入し研修 医に説明を行っている. 厳しい状況に陥っている地方外科医療に対し 新専門医制度を外科医増加と若手教育にうまく利用できないか暗中模 索している.

〈略歴〉

昭和 56 年 3 月広島大学医学部卒業

6 月 鹿児島大学医学部第 1 外科入局

$\begin{array}{ll}\text { 昭和 } 58 \text { 年 } 4 \text { 月〜昭和 } 61 \text { 年 } 3 \text { 月 } & \text { 出張病院にて研修 } \\ \text { 昭和 } 61 \text { 年 } 4 \text { 月〜昭和 } 63 \text { 年 } 3 \text { 月 部内研究生 }\end{array}$

昭和 63 年 4 月 平成 2 年 9 月 出張病院勤務

平成 2 年 10 月 鹿览島大学医学部第 1 外科助手

平成 8 年 4 月〜平成 9 年 6 月 ドイッ・ミュンヘン工科大学 (Prof. Siewert) 留学

平成 11 年 7 月 鹿児島大学医学部第 1 外科講師

平成 16 年 3 月 鹿児島大学医歯学総合研究科腫瘍制御学・消化器外

科学准教授

平成 21 年 1 月 鹿翼島大学医歯学総合研究科消化器 - 乳腺甲状腺外

平成 27 年 4 月 科学教授, 現在に至る

〈学会活動〉

日本外科学会

代議員, 臨床研究推進委員会委員, 都道府県安全管理責任者

日本消化器外科学会

理事（2010 2016), 評議員, 広報委員会委員長, 専門医制度委員

会委員, 資格認定委員会委員, 医療安全委員会委員, 将来構想委員 会委員, 外科関連学会協議会代表委員, 評議員選出委員会地区委員, 学術集会運営委員会委員, 学術委員会委員, 学会創立 50 周年記念 事業準備委員会委員

日本食道学会

監事 (2016～)，理事（2009 2015），評議員，用語委員会副委員長， 会誌編集委員会委員, 専門医制度委員会委員, 食道専門医認定医認 定部会委員, 食道専門医カリキュラム設定部会委員会, NCD 部会 委員, 医療安全委員会委員長

日本胃癌学会

評議員, 胃癌取扱い規約委員会委員, 会則委員, 選挙管理委員会委

日本癌治療学会

代議員, 将来計画委員会委員

日本臨床外科学会

評議員

日本消化器病学会

九州支部評議員, 学術研究助成金選考委員会委員

日本消化器癌発生学会

理事, 評議買, あり方委員会委員長

日本リンパ学会

常任理事, 編集委員

日本胸部外科学会

評議員

日本がん転移学会

理事, 評議員

日本大腸肛門病学会九州支部

幹事, 評議員

日本胸部外科学会九州地方会

評議員

〈尃門分野〉

消化器・乳腺甲状腺癌の外科治療と術前診断, 消化器 - 乳腺甲状腺癌 の悪性度に関与る分子生物学的・遺伝子学的研究, 癌の微小転移, 消 化器・乳腺甲状腺癌化学療法に関委る研究
総会特別企画 $01-2$

新専門医制度とこれからの若手外科医 の育成一女性若手外科医育成の観点か ら一

東京大学 消化管外科学

野村幸世

日本外科学会では新専門医制度の発足

へ向けてプログラムを作成中である。

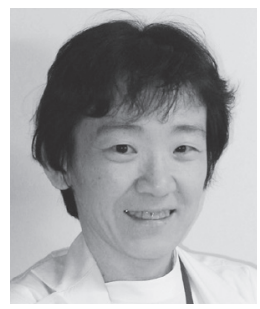

日本外科学会では現在の女性会員割合は $8.2 \%$ であものの、 新入会員における女性割合は $19.9 \%$ であり、特に若手の女性外 科医は確実に増加しつつある。日本の医学部学生における女性 の割合は $50 \%$ に近づきつつある。日本外科学会の会員数は減 少傾向にあり、外科への女性の参画が望まれる。一方、日本は 少子高齢化に悩む国であり、出生率は 1.5 を割り、1 1 近づき つつあり、人口減少は加速している。人口減少に歯止めをかけ るためには、働く女性にも出産をしてもらう必要がある。医学 部を卒業すると大体 25 歳に達している。その後、新診療研修 制度にのっとり、研修を 2 年間行うと 27 歳。専門医制度研修 を 3 年行うと 30 歳となる。ところが、女性の結婚年齢と生涯 不妊率とを見ると、25-29歳の結婚では生涯不妊率約 10\%、 30-34歳では約 18\%、35-39歳では約 30\%、40-44歳では 60\% と なる。不妊治療でも、生産率/総治療は 30 歳では $20 \%$ 程度あ つたものが、35歳で $17 \% 、 40$ 歳で $8 \%$ 、4 歳でほほ $0 \%$ となる。 外科の臨床研修を経験した立場からは、決して、早期の研修時 期における出産を勧めないが、年齢を考慮するとやむをえない 部分もあるように思う。なんとか 30 代前半で出産できる労働 環境と研修の効率化が望まれる。

〈略歴〉

1989年 3 月

東京大学医学部医学科卒

1994年 4 月

1998年 4 月

入局

東京大学大学院医学系研究科外科 学専攻入学 東京大学大学院医学系研究科外科 学専攻卒業

博士 (医学)

東京大学医学部付属病院分院外科 助手

2002 年 5 月一 2005 年 3 月 Department of Surgery, School of Medicine, Vanderbilt University

2005 年 4 月一 2007 年 3 月 東京大学大学院医学系研究科消化

2007 年 4 月一 管外科学講座、講師

2011 年 9 月一 同 准教授 東大病院がん相談支援センター長 兼任

現在に至る 


\section{総会特別企画 $01-3$}

新たな専門医制度における呼吸器外科

専門医

静岡市立静岡病院 呼吸器外科

千原幸司

2018年 4 月に新専門医研修制度が始まる。 日本呼吸器外科学会と当委員会は外科專 門医研修とサブスペシャリティとしての

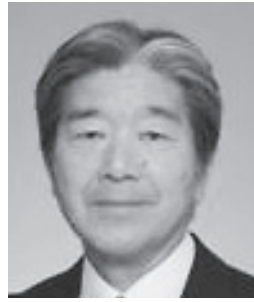

呼吸器外科曺門医研修が連動する呼吸器外科専門医志向型のプログラ 厶を軸に専門医に提示して、今後も需要増加が見込まれる呼吸器外科 専門医を育成することを目指している。むろん、2つが直列あるいは 外科専門医取得後に診療や研究に従事した後、呼吸器外科専門医を目 指す医師も研修プログラムを受けることも可能とする。呼吸器外科を 志向する専攻医は呼吸器外科をべースにしてプログラムに属し、ロー テーションでほかの領域を研修し、多く経験する呼吸器外科手術経験 は外科専門医取得のための必須 350 例の核とある。新制度は基本領域 +subspecialtyの 2 階建てが基本骨格なので呼吸器外科専門研修登録 開始は 2021 年となるが、外科専門医研修期間中の呼吸器外科手術経 験は呼吸器外科専門研修に有効な経験として組み込み、卒後 8 年目で 新規申請が可能となるプログラムを予定している。核家族、一人暮ら しが増えた高齢化社会における国民の負担を聥隇できるよう、我が国 のひろくあまねく身近な施設で標準的な呼吸器外科診療を提供できる subspecialityとしてのコンピーテンシーを有する呼吸器外科専門医を 養成して供給すること、そして制度の対象である若い医師が medica specialityのプログラムを修了したと CVに記載できることが呼吸器外 科専門医制度の目標になると考える。

\section{〈略歴〉}

静岡市立静岡病院副病院長兼呼吸器外科長、京都大学医学部臨床教授 1978 京都大学医学部卒業、

1978-1983 京都大学胸部疾患研究所と静岡市立静岡病院で呼吸器外 科と心臓血管外科の研修

1983 京都大学大学院医学研究科

1987 京都大学胸部疾患研究所胸部外科助手

1989 McGill大学 (Canada) 医学部内科客員助教授

1991 静岡市立静岡病院呼吸器外科長

2005 診療部長兼務

2013 副病院長、麻酔科長、シミレーション・ラボラトリー室長兼 務

2014 リハビリテーション科長、手術室科長兼務

2015 副病院長、呼吸器外科主任科長、手術室主任科長、リハビリ テーション主任科長、災害医療対策管理室長、シミレーショ ン・ラボラトリー室長

現在に至る

〈資格〉

呼吸器外科専門医、外科専門医、呼吸器専門医、日本呼吸器外科学会 指導医、日本胸部外科学会指導医、日本外科学会指導医、日本呼吸器 学会指導医、日本がん治療認定機構暫定教育医、日本臨床腫瘍学会暫 定指導医、麻酔標榜医、日本DMAT隊員

〈学会〉

日本呼吸器外科学会理事 (三期)、監事 (二期)、呼吸器外科専門医合 同委員会委員長、日本胸部外科学会理事（二期）、3 学会呼吸療法認 定士委員会委員、日本外科学会倫理委員会・専門医制度委員会委員、 日本肺癌学会将来計画委員会委員・倫理委員会、日本呼吸器学会専門 医制度審議委員会専門医資格委員会委員

〈社会的活動〉

NPO災害・医療・まちづくり理事

静岡県災害医療コーディネーター、静岡市災害医療コーディネーター

一般社団法人日本専門医機構専門医制度検討委員会

一般社団法人日本専門医機構基本領域研修委員会委員

$\langle$ Reviewer(Consultant)

CHEST, 日本呼吸器外科学会雑誌、日本呼吸器学会雑誌, General Thoracic Cardiovascular Surgery, Respirology, Inernal Medicice、 Surgery Today, Respiratory Investigation (Associate Editor) 〈授賞〉

1. Young Investigator Award : Development and clinical application of cuirass negative pressure respirator synchronizing spontaneous breathing.

「自発呼吸を感知して作動する cuirass 型陰圧式人工呼吸器の開発 と臨床応用」

the 54th Annual Assembly of American College of Chest Physicians ( ACCP ), 1988

2. Pneumoforum研究奨励賞：肺気腫の外科治療,2002

3. Best Poster Award: Reconstruction of Phrenic Nerve,11th Asian Pacific Society of Respirology (APSR),2006

〈主な研究テーマ〉

呼吸器悪性腫瘍の外科治療

呼吸機能の温存/改善、そして補助

肺気腫の外科治療

\section{総会特別企画 $01-4$}

新専門医制度に向けて一現心臓血管外 科専門医制度の問題点と改善策— 東京慈恵会医科大学心臓外科 橋本和弘

若手育成のための問題点 1 ）心臓血管 外科専門医の定義・実力が国民に分か りにくく、国民のイメージを反映して

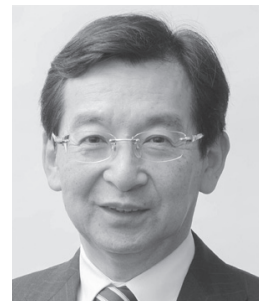
いないこと、2）心臓血管外科専門医と標榜しながら、現実的 に心臓・大血管疾患、小児心疾患、腹部 · 未梢血管疾患全てを 必ずしも経験していないこと、3）少例数の修練施設が多く、 十分な修練が得られず、専門医取得までに15年を要している こと新制度に向けての改善策 1 ）心臓血管外科専門医の定義全 ての疾患（成人・小児心疾患、動・静脈）の専門知識と同時に 外科的治療技術を兼ね備えた医師、ただし手術に関しては独立 して治療できるレベルを保証するのではなく、チームとして参 加し、与えられた手術の一部を責任持って遂行できるレベルの 医師とする。2）知識、経験の偏りの是正 新制度においては 成人心 ·大血管疾患、先天性心疾患、腹部 · 未梢血管疾患の 4 領域全ての修練を義務化する。3）専門医取得までの修練期間 の短縮 連動型プログラム制を導入し、初期研修終了後 5 年で の取得を目指す制度とし、専攻医にロードマップを提示する。

4) 手術経験新制度においては病院群を形成し、症例数を確保 し、その症例数に見合った定員を設け、修練に必要な症例数を 担保し、施設間のローテーションにより、幅広く効率よい修練 を行うことを可能とする。更に、新規申請者には受験までに 30 時間のSimulation、Dry \& Wet Labの経験を義務化し、Off The Job Training の習慣化を促す。

〈略歴〉

1978年＼cjkstart東京慈恵会医科大学卒業

2002年～東京慈恵会医科大学 心臓外科主任教授

2014年～東京慈恵会医科大学 副学長

2012年～心臓血管外科専門医認定機構代表幹事

現在、日本胸部外科学会理事、日本心臓血管外科 学会理事

$\langle$ Profile〉

School Attended

Jikei University School of Medicine April, 1973 to Mar, 1979

Professional Training and Employment:

Assistant Professor in the Dep. of Cardiac Surgery, Jikei

University Hospital from April 2002 to August, 2002

Professor and Chairman in the Dep. of Cardiac Surgery,

Jikei University Hospital from September 2002 to present

Membership

The Japanese association for thoracic surgery (Councilor)

The Japanese society for cardiovascular surgery (Councilor)

President of Japanese Board of Cardiovascular Surgery

Active member of American association for Thoracic Surgery, etc. 


\section{総会特別企画 01-5}

米国からみた新専門医制度とこれから の若手外科育成を考える

Harvard University, Brigham and Women's Hospital 心臟外科 金子剛士

現在日本の専門医制度は元来の学会主

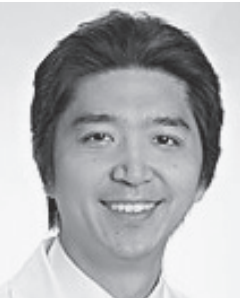
導の資格取得から第三者機関認定の制 度への移行を行㧍としている。アメリカでは第三者機関、 American Board of surgery が専門医の資格の授与を1937年か ら行っており、現在 6 万人の外科医がこの資格を有している。 一方でこの専門医の資格は外科教育すなわち一般外科レジデン シーと密接に結びついている。アメリカの外科教育の光と影に も結びつく American Board of surgeryの現状を日本の外科教 育と比較し、今後の日本の外科専門医制度について検討する。

〈略歴〉

Director, Aortic Center

Director of Clinical Outcomes Research

Associate Director of Endovascular Cardiac Surgery

Brigham and Women's Hospital

Assistant Professor, Harvard Medical School

2002 年 慶應義塾大学医学部卒業

2005年 慶應義塾大学病院一般外科レジデント

2006年＼cjkstart慶應義塾大学病院心臓血管外科レジデント

2007年 New York Medical College Bronx Program 一般外 科レジデント

2011年 University of Texas at Houston一般外科レジデント

2013年 Brigham and Women's Hospital心臟胸部外科レジデ ント

2014年Ｄuke University 心臟外科レジデント

2015年より現職
総会特別企画 02-基調講演

地域医療と外科の現状と課題

大分大学 地域医療学センター（外科 分野)

白石憲男

「国民は、いつでも、どこでも、安 価で最高の医療を受けることができ る」という国民皆保険制度のもと、我

が国では質の高い医療が実践されてきた。地方に沶いても 1 県 1 医大構想により設立された医学部が地域への人材育成と派遣 の中心的な役割を担ってきた。しかしながら、21世紀に入り、 医療の高度化や少子高齢化が進むにつれて、医療費の高騰や地 域医療の崩壊が生じている。

特に、地域医療の崩壞をもたらしたのは、2004年に始まっ た研修医制度である。General physicianを育てるという意図 のもと、「開かれた競争」であるマッチング制度の導入や外科 の必修化の廃止などの結果、外科志望者の減少と大学医局への 非入局者の増加をもたらし、地域外科医療の崩壊を加速させた。 これまで、外科医や女性外科医の職場環境の改善や医療事故へ の対応などが講じられてきたが、著明な改善を認めていない。

現在、病床機能の再編、地域医療ビジョンの策定、地域連携 や地域包括ケアの構築などの医療改革が進められており、外科 医の立場も多様化している。一方、国際基準に準じた卒前教育、 初期研修、専門医制度などの医学教育改革も進められており、 外科医の育成についても議論が多い。このような制度改革の中 で、良質な外科医療を維持し、外科志望者の増加、外科医の育 成、地域への外科医の分布調整と連携構築のため、外科医の意 識改革と新しい視点に立った方策が求められている。

〈略歴〉

1984年 3 月 大分医科大学医学部医学科卒業

1988 年 3 月 大分医科大学大学院医学研究科生理系専攻博士 課程修了

1988年 4 月 田上温泉病院外科医師

1988年11月 米国国立衛生研究所 $(\mathrm{NIH})$

Developmental Biology and Anomalies, NIDR 部 門 Visiting fellow

1991年 5 月 大分医科大学医学部附属病院 (外科第 1 ) 医員

1991年 6 月 御手洗病院外科医師

1992年 4 月 大分医科大学医学部附属病院（外科第 1 ) 医員

1994年 4 月 大分医科大学医学部 (外科学講座第 1 ) 助手

2000 年 4 月 大分医科大学医学部 (外科学講座第 1 ) 講師

2003 年 4 月 大分医科大学医学部 (外科学講座第 1 ) 助教授

2007 年 4 月 大分大学医学部 (外科学講座第 1 ) 准教授

2010 年 2 月 大分大学医学部地域医療学センター (外科分野) 教授 
総会特別企画 02-1

地域外科医療からみた地域医療構想の

問題点

旭中央病院 外科

田中信孝, 野村幸博, 古屋隆俊, 永井元樹, 吉田幸弘, 平野稔,

石田隆志

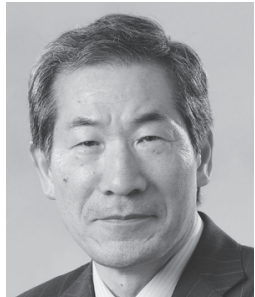

地域により医療事情が全く異なる中で、どの医療機関でも共通 した課題は医師不足であろう。大学からは医局との関連病院で ないかぎり、まず医師派遣が望めないし、そうでなくても移動 を拒めない。旭中央病院は千葉県の北東部、人口約 30 万人の 香取海市 2 次医療圈にある989床の大規模地域中核病院である。 現在、専攻医を含めて外科医 23 人体制となるまで拡張した。 演者赴任以来、大学医局との一定の関係性を保ちつつ外科体制 の充実に努めた結果であるが、医療過疎という地の利を逆利用 乙、総合外科 (一般外科 - 消化器外科 - 内視鏡外科 - 血管外科 · 呼吸器外科 - 乳腺内分泌外科 - 外傷外科を包含）と称して、先 輩外科医のオールラウンドマルチプレーヤーのスタイルを後続 の医師にも伝達することを基本とし、誰でもがどの分野でも指 導医になれるような体制を構築していった。外科手術件数は増 加の一途をたどっている。一方、当地域にはほかに中小規模の 6つの自治体立病院があるが、新臨床研修制度による医師の大 学病院への引き上げをきっかけとして医師不足となり、過去 12 年間経営好転のきざしがない。当院が巨大化したワンスト ップ総合病院となる一方、近隣医療機関は後方病院としての機 能をも十分果たせず外科医療でも苦闘が続く。新公立病院改革 プランに加え、地域医療構想にあたっての病床機能の明確化が 求められる中、中核病院以外での外科医療は岐路に立たされて いる。

〈略歴〉

1973 年 9 月 東京大学医学部医学科卒業

東大第一外科および茨城県立中央病院で外科研修

1977 年 4 月 兵庫医科大学第一外科助手

岡本英三教授のもと肝臓外科を学ぶ

1983年 4 月〜1985年 7 月 スウェーデン国ルンド大学外科留学 Prof. Bengmarkのもと、Biliary Sepsis で PhD 取 得

1987 年 4 月 兵庫医科大学第一外科講師

1991 年 8 月 総合病院国保旭中央病院外科部長

1999年 7 月 総合病院国保旭中央病院副院長

2013年 3 月 総合病院国保旭中央病院院長

2016 年 4 月 地方独立行政法人総合病院国保旭中央病院 副理 事長兼病院長

〈学会活動〉

日本外科学会 指導医 専門医 認定医

日本消化器外科学会 指導医 専門医

日本消化器病学会 指導医 専門医

日本肝臓学会 専門医

日本臨床外科学会 評議員

日本手術医学会 評議員

日本医療マネジメント学会 評議員

日本医療バランスト・スコアカード研究学会 評議員
総会特別企画 02-2

地域・へき地医療を支える外科医の役 割と展望

都志見病院外科 ${ }^{1)}$, 萩市福川診療所 ${ }^{2)}$, 山口県立総合医療センターへき地医療 支援部3)

山本達人 ${ }^{1)}$, 三好康介 ${ }^{2)}$, 原田昌範 ${ }^{3)}$

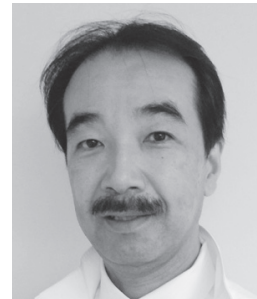

当院は高歯化率 $39 \%$ 、医療圈人口 53000 人、3 次医療圈まで陸 路 1 時間強のへき地に立地している。医師不足、医師の高齢化、 診療科の偏在のために外科医は手術以外に麻酔、救急、消化器 内視鏡検查、がん化学療法、ICT、NST、緩和ケア、災害医療、 在宅診療、他科の手術助手等の役割を担っている。ネガティブ な表現をかりると「古き悪しき外科の慣習」が存続しているー 「便利屋として外科医が重宝されている」ということになるが、 地域医療の存続のためには外科医の役割が極めて重要である。 外科医に対するインセンティブとして 1）金銭的・経済的サポ ート、2）業務軽減を意眓した人的サポート、3）キャリア形 成・維持をサポートする体制等を導入し評価を得てきた。診療 面では心臓血管外科、放射線治療、腹部IVRが提供できない 体制となり外科疾患が縮小しているが、外科医のモチベーショ ンを維持すると同時に地域外科医療を後退させないために、鏡 視下手術をはじめとした先端医療の手術手技を導入している。 また、地域を担う次世代外科医の育成を目指して医局や大学の 壁を越えた外科志望者の受け入れ体制を整備し離島やへき地診 療所勤務医の外科専門医習得や更新に協力している。今後、先 細りする地域の中で外科医療を継続的に維持するためには、地 域内で完結できる外科機能の集約と対応できない外科機能を他 医療圈と連携することで外科医をとりまく環境を整備すること が重要であると思われる。

〈略歴〉

1987 年 3 月 山口大学医学部卒業、山口大学第二外科（消化器 ·腫瘍外科）入局

1991 年 3 月 山口大学大学院医学研究科外科系外科学専攻博士 課程所定単位修得

1991 年 4 月 山口大学付属病院総合治療センター

1991年 10 月 都志見病院外科

1993 年 8 月 総合病院社会保険徳山中央病院外科

1995年 4 月 都志見病院外科

1999 年 4 月 同院：外科部長

2012年 8 月 同院：副院長 現在に至る

〈資格、役職等〉

山口大学医学部臨床准教授

日本臨床外科学会：評議員

日本外科感染症学会：評議員

山口県臨床外科学会 : 副会長

山口県医師会勤務医部会：理事

日本外科学会指導医・専門医

日本消化器外科学会指導医・専門医

日本がん治療認定医機構がん治療認定医・暫定教育医

日本外科感染症学会外科周術期感染管理認定医 - 暫定教育医

日本プライマリーケア連合学会指導医・認定医 


\section{総会特別企画 $02-3$}

離島における外科診療の問題点と対策 長崎県上五島病院

八坂貴宏

【はじめに】離島病院に勤務する外科 医の立場より離島における外科診療の 問題点と対策について検討した。【問 題点】1、海で隔絶される地域ではす べての救急疾患に対応しなくてはならない。2、高齢者が多く 多彩な疾患管理や複雑な IC を要求される。3、診断から手術、 化学療法、看取りまで一連のケアを行う必要がある。4、病院 規模は小さいが手術室や医療機器の整備、病診連携の綿密さが 要求される。5、医師不足。6、専門医取得が困難でキャリア パスが描きにくい。【対策】1、2、3 は、幅広い知識や技術 を持ち、病気ではなく人を診る総合外科医の養成が必要である。 外科医として、ヘルニア、急性虫垂炎、胆道疾患、消化管穿孔、 消化器癌など日常的に遭遇する外科疾患に対応でき、総合医と して、化学療法や緩和ケア、高齢者医療を実践できる能力が必 要である。4 は、管理者の効率的病院運営や医療機能再編・ネ ットワーク化で対応できる。 5 は、初期臨床研修制度、専門医 制度で地域医療を視点に置いたプログラム作成や定数設定を期 待したい。6は、地域病院での外科医の資質、技能を評価して ほしい。また本土と離島を循環できる制度を考えたい。【まめ】 臓器を診て人を診ず、先端を追求して基礎を知らずとなれば、 外科診療の本質を失いかねない。若い外科医の教育においては 地域病院でこそできるものも多く、全人的、地域的な視点を持 った総合外科医の養成も必要と考える。

〈略歴〉

1988年 長崎大学医学部卒 (学生時代には長崎県医学修学資 金を貸与)

1988年＼cjkstart長崎医療センター（初期研修）

1990年 長崎県上五島病院

1993年＼cjkstart長崎医療センター（後期外科研修

1994 年 国立がんセンター、癌研究会付属病院（後期外科研修

1995年 生月町立生月病院

1997年 長崎県上五島病院

2004年 長崎県上五島病院 副院長

2007 年 長崎県上五島病院 院長

現在に至る

\section{総会特別企画 $02-4$}

離島で一般外科医を続けて〜総合一般 外科のモデルと女医の問題〜 沖縄県立宮古病院 外科

\section{浅野志麻}

一般外科の修練は重要な基礎とされ、 外科医として成長するために一般外科 の修行を積んだ後サブスペシャリティ

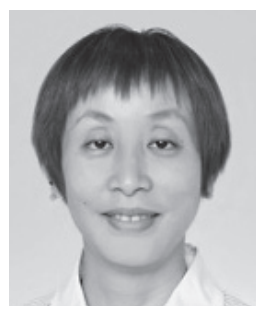

とされる分野に進むことが期待されている。離島の外科臨床の 現場では一般外科が中心であり、サブスペシャリティに特化す ると成り立たなくなる一方、一般外科だけでは高度な技術を要 する手術に携われないジレンマがある。離島で長期にわたり臨 床を行なっているがこの問題が中核にずっと存在し、慢性的な 人手不足に陥っている。離島だけでなく大都会ですら中小病院 でも同じ問題を抱えており、全国的な問題であるととらえてい る。若手外科医にとってサブスペシャリティの取得が困難なこ とはすなわちそこでの診療は将来無駄になるととらえられてし まう傾向があるが、現場のニーズは総合的な一般外科疾患が圧 倒的に多く、現場と大きなギャップが生じている。地域の外科 を支える「総合一般外科医」のモデルを作成しサブスペシャリ ティとの関わりや今後の問題点を提起した。外科医のイメージ の改変が今後の外科全体の発展に大きく関わると考えている。 離島に勤務する女医の問題（妊娠、出產、パートナーとの関係） についても紹介し議論のきっかけとしたい。

〈略歴〉

1998年＼cjkstart青山学院大学国際政治経済学部卒業

2004 年 東京医科歯科大学医学部卒業

2006年 沖縄県立中部病院初期研修医修了

2009 年 沖縄県立中部病院後期研修医修了

2008年 4 月～ 沖縄県立宮古病院外科

外科専門医取得（2011年） 


\section{総会特別企画 $02-5$}

大学医局関連病院との連携による僻地・過疎地域での外科医の モチベーションの向上の工夫

下呂市立金山病院外科 ${ }^{1)}$, 岐阜県総合医療センター外科 ${ }^{2}$, 岐 皁大学腫瘍外科 ${ }^{3}$

今井健晴1.3)，須原貴志 ${ }^{1)}$ ，古田智彦1)，河合雅彦 ${ }^{2)}$ ，國枝克行 ${ }^{2)}$, 高橋孝夫 ${ }^{3}$, 吉田和弘 ${ }^{3)}$

下呂市立金山病院（以下，当院）は岐阜県飛駢地方南部の山間 部にある急性期 50 床, 療養 49 床, 医師 7 人の僻地小病院で ある. 外科はべテラン 2 人と岐阜大学腫瘍外科医局から派遣さ れる若手 1 人である。一般外科のみならず整形外科や脳外科な ど総合的な外科疾患が経験でき, 自らが地域住民の生命を守っ ていると実感できることが僻地外科医療の醍醐味といえる。一 方で血液の備蓄が無く, 麻酔科専門医もいないため, 高難度手 術の場合や周術期管理の困難が予想される患者の場合には，遠 隔都市部の大病院に紹介している。そういった場合，従来は当 院では手術後の追加治療や外来フォローだけを行っていたた め，僻地では高難度手術の腕を十分に磨くことが出来ないとい うモチベーションの低下を感じることがあった，また，外来フ オローアップだけ担当するため, 患者との信頼関係を十分に築 くことができない，当院への転院後にスムーズに管理できない といった患者側への問題も生じ, 若手だけでなくべテラン外科 医も長年抱いてきた切実な悩みであった。この現状を打開する ため, 2009 年 4 月より医局関連病院と連携し, 紹介した患者 とともに主治医も移動して手術に参加する取り組みを始めた. 成果は外科医のモチベーションの維持にとどまらず，患者，関 連病院, 当院のいずれにも在院日数の短縮あるいは病床利用率 の改善等の様々な意義がみられた。僻地外科医療を経験した若 手外科医の目線から紹介する。

〈略歴〉

$\langle$ 学歴・職歴〉

2001年 岐阜県立斐太高等学校卒業

2007 年 高知大学医学部卒業

同年 岐阜県総合医療センター初期臨床研修

2009 年 岐皁大学腫瘍外科入局

同年＼cjkstart岐阜県総合医療センター外科

2010年 高山赤十字病院外科

2011年 愛知県がんセンター中央病院 消化器外科レジデント

2013 年 下呂市立金山病院外科

2015年＼cjkstart岐阜大学大学院入学 現在に至る

〈所属学会・資格〉

日本外科学会 (専門医) 日本消化器外科学会

日本臨床外科学会日本癌学会日本癌治療学会

日本救急医学会（ICLSインストラクター）

日本外傷診療研究機構 (JATECインストラクター)

マンモグラフイ読影認定医 等

\section{総会特別企画 02-6}

岩手県における救急と地域救急医療に おける外科診療の問題点

岩手県立磐井病医院

佐藤耕一郎

1 ) 岩手県における救急と 2 ) 県南の当院 救急医療における外科診療の問題を検討 した。1）2014年の20ある県立病院の救

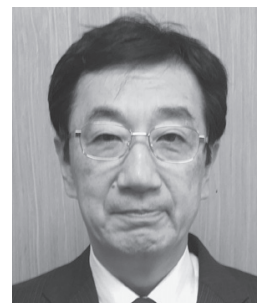
急の状況を 2 次医療圈別救急搬送数、 $1 \cdot 2$ 次患者割合、県南地区の 2 次救急輪番制度で検討した。結果、ほとんどの 2 次医療圈で $70 \%$ 以 上の救急搬送が県立病院に行われ、救急の $80 \%$ 以上は軽症の 1 次救急 であった。また、県南の 2 次輪番制度は崩壊して県立病院に負担がか かっており、原因は救急隊が 2 次輪番制度を守らず多くの患者を県立 病院に搬送しているためであった。2 2) 2015 年度の当院の救急患者 13560 人のうち入院は 3257 人 $(24 \%)$ で、外科入院の 285 人の $81.4 \%$ は 時間外であり、約 $1 / 3$ は手術が必要であった。入院理由はイレウス が $21.4 \%$ (61 人) と一番多く、その $15 \%$ （9 人）は大腸癌イレウスで あり、全例に緊急手術かステント留置が必要であった。原因はトイレ 水洗化の遅延により血便に気付かないためと考えられた。また 2 年前 より日赤による当院での備蓄血液廃止により、血液搬送に約 1 時間弱 かかるため当院では $\mathrm{O}$ と $\mathrm{A}$ 型を 4 単位ずつ常備している。外科で緊急 輸血が必要になった 12 症例での死亡は外傷性肝損傷、食道癌大動脈 穿通の 1 例ずつであったが、輸血の遅延が原因の死亡ではなかった。 問題解決の方法として他院との 1,2 次救急の分担が急務であり、救急 搬送基準を 2 次救急輪番制度を生かした基準に変えること、便潜血検 査を受けること、もっと早く大量輸血ができる仕組みの確立が重要と 考えられた。

〈履歴〉

1977 (S52)

1984 (S59)

盛岡第一高校卒

1984 （S59） 5.1 岩手県立北上病院外科勤務 研修医 2 年

1986 （S61）4.1 東北大学第二外科入局 医員 5 か月

1986 (S61) 9.1 岩手県立花巻厚生病院外科勤務 医師 1 年 1 力月

1987 （S62） 10.1 東北大学第二外科 医員 7 年 2 力月

1995 （H 7 ） 1.1 市立酒田病院外科 副科長 3 か月

1995 (H 7 ) 3.31 東北大学大学院研究科卒

1995 (H 7 ） 4.1 公立気仙沼病院外科 医長 2 年

1997 (H 9 ) 4.1 ハーバード大学留学(Research fellow) 2 年 7 カ月

1999 （H11） 9.1 仙台社会保険病院外科 医長 1 年 7 力月

2001 （H13） 4.1 総合花巻病院外科 医長 1 年

2002 (H14) 4.1 NTT東日本東北病院外科 医長 2 年 4 力月

2004 （H16） 8.1 釜石市民病院外科 外科科長 8 力月

2005 (H17) 4.1 岩手県立釜石病院外科 外科科長 1 年 5 力月

2006 （H18） 9.1 岩手県立磐井病院外科 外科科長 4 年 6 力月

2011 (H23) 4.1 岩手県立磐井病院外科 副院長兼外科科長

2012 （H24） 4.1 岩手県立磐井病院外科 副院長兼臨床研修科長

2014 (H26) 4.1 岩手県立磐井病院外科 副院長兼乳腺内分泌外科科長

〈資格〉

外科学会指導医

外科学会専門医

消化器外科学会指導医

消化器外科学会専門医

内分泌 - 甲状腺外科専門医

乳腺専門医

乳腺認定医

ICT

消化器外科化学療法専門医

〈所属学会〉

日本外科学会

日本消化器外科学会

臨床外科学会

日本乳癌学会

日本内分泌外科学会

日本救急医学会

甲状腺外科学会

外科系連合学会

日本医療マネージメント学会

日本クリニカルパス学会

日本オンコプラスチックサージャリ一学会

日本甲状腺外科学会 


\section{総会特別企画 $02-7$}

地域包括ケアにおける外科医の役割

手稲渓仁会病院

樫村暢一

2025 年に向かい、高齢者人口の急激 な増加は、高齢者の医療、介護、終末 期ケアニーズを著しく増大させてい る。また、2030年の推計死亡者数は

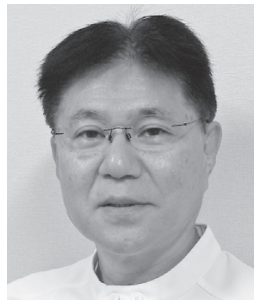

160 万人とされ、見取り場所の確保を含めた高齢者ケアの場が 必要となっている。そこで、「地域」で（が）「包括ケア」を提 供する「地域包括ケアシステム」の構築が必須となってきた。 その定義は、“ニーズに応じた住宅が提供されることを基本と した上で、生活上の安全、安心、健康を確保するために、医療 や介護、予防のみならず、福祉サービスを含めた様々な生活支 援サービスが日常生活の場面で適切に提供できるような地域で の体制”となっている。しかも、地域の実情に合わせて手作り で仕上げるシステムとされる。その中で外科医に期待される役 割として、1.良質な急性期医療の提供と地域全体の救急医療 体制の構築, 2 . 地域での役割分担と機能連携の推進（退院支援、 在宅医療、緩和ケアを含む終末期医療、介護・福祉との連携)、 3 . 疾病予防、介護予防、高齢者の社会参加など予防医学普及 への協力、 4 . 健康医療福祉の総合的な地域づくりへの参画な どが挙げられる。今後も手術を主体とする専門医療を提供する 本来の役割は変わらないが、地域の医療者の一人として、住民 （高齢者、患者）を生活視点でケアする様々な取り組への理解 と参画が期待される。外科医の年齢や立場、勤務地域などによ り果たす役割は変化するが、専門領域を超えた活動が求められ ている。

\section{$\langle$ 略歴〉}

〈学歴、職歴〉

1978年 3 月 北海道大学医学部卒業

1978 年 4 月 北海道大学医学部第 2 外科（現：消化器外科 II 入局 北海道大学医学部付属病院勤務

1978年 6 月 市立札幌病院 麻酔科研修

1979年 6 月 国家公務員共済組合連合会 斗南病院外科勤務

1980年 6 月 市立釧路総合病院 外科勤務

1981 年 4 月 北海道大学医学部付属病院 第 2 外科勤務

1984年 4 月 室蘭太平洋病院 外科医長

2004年 4 月 手稲渓仁会病院 副院長

2006 年 4 月 手稲溪仁会医療センター 手稲溪仁会クリニック 院長

現在に至る。
1987 年 12 月 手稲渓仁会病院 外科部長

\section{総会特別企画 03-コメンテーター}

膳場貴子 キャスター。

大学で健康科学・看護学を専攻後、97

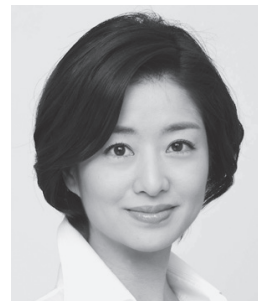

TBS系列「報道特集」(土曜 $17: 30)$

「おはよう日本」「プロジェクトX」「紅白歌合戦司会」などを 担当後、退職。

'06 年から今年 3 月までTBS「NEWS23」キャスターを務める。 昨年出産、一女の母。 
総会特別企画 03-1

災害医療対応〜外科医として知るべき

こと、やるべきこと〜

国立病院機構 災害医療センター 小井土雄一

平成 17 年から始まったDMAT隊員盖 成研修も、1,500チーム、10,000 人を 超えた。医師 3,000 人の大半は救急医、

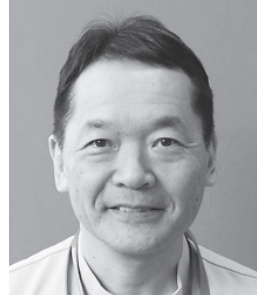

外科医が占める。長期型自然災害（洪水等）では、外科的医療 ニーズは低いが、短期型自然災害（地震等）では、外科的医療 ニーズが高い。東日本大震災では、津波が発生し負傷者含めて さらわれてしまったが、首都直下地震では、負傷者約 15 万人、 重傷約 2 万 2 千人が見込まれている。首都直下地震は、外科的 な医療ニーズは莫大であると考えて良い。その意味で、 DMATが救急医、外科医が多いことは理に適っている。一般 の外科医は、災害医療システムを学んでおくべきであろう。 EMIS (広域災害救急医療システム)、災害拠点病院、広域医療 搬送などを理解していることが重要である。その意味で、外科 医に限らず、災害医療はすべての医療者が学ぶべきものである。 人為災害に拀いては、昨今国際的にテロが多発している。我が 国も国内でテロが起きないとは断言できない。すべての外科医 は多数傷病者対応の矢面に立たされる可能性がある。基本的に は、外科医は、災害時においても外科医にしかできないことを すべきである。すなわち、手術室で手術をするということが外 科医の第一優先になる。ただ、平時では経験しない銃創、爆傷 の手術に遭遇する可能性もあり、トレーニングが必要である。 また、多数傷病者を遅滞なく手術室へ運ぶには、1 病院の対応 ではなく、地域でのシステム作りが不可欠である。

\section{〈略歴〉}

1957年 9 月 2 日生まれ

昭和 59 年 3 月 埼玉医科大学卒業

昭和 59 年 6 月 日本医科大学救急医学教室入局

昭和 63 年〜平成 2 年 クイーズランド肝移植機構留学 (オー ストラリア)

平成 9 年 10 月 日本医科大学講師

平成 19 年 4 月 川口市立医療センター救命救急センター部長

平成 20 年 4 月 独立行政法人国立病院機構災害医療セン夕 - 臨床研究部長

平成 21 年 4 月 災害医療センター 救命救急センター長 併

平成 22 年 4 月 厚生労働省医政局災害対策室 DMAT 事務局 事務局長 併任

平成 27 年 2 月 日本集団災害医学会 代表理事 $\langle$ 現職〉

独立行政法人国立病院機構 災害医療センター

臨床研究部長・救命救急センター長

厚生労働省 DMAT事務局 局長

日本集団災害医学会 代表理事

日本医科大学 連携准教授

埼玉医科大学医学部客員教授

東京医科歯科大学医学部 臨床教授

東京医療保健大学大学院 看護学研究科 臨床教授
総会特別企画 03-2

パリ同時多発テロ事件における医療対 応の実際

東京大学 救急医学

森村尚登

【はじめに】2015年11月にフランスの パリ市街中心部と周辺地域において。 同時多発の銃撃・爆弾テロが起き、大

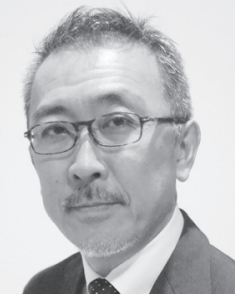

惨劇となったことは記滰に新しい。パリ公立病院連合 (APHP) と公立救急医療支援組織（SAMU）の情報提供に基づき、初 期医療対応を報告する。【概要】同国は、多数傷病者発生事故 を中心とした纴害対応計画として、病院前、病院内・間、同時 多点対応を策定している。現場で判断する緊急度は絶対緊急 (AE) と相対緊急 (RE) の 2 類型。爆傷・銃創時の現場対応 として、ターニケット・凝血促進剂含浸ガーゼの積極的使用等 による外出血制御、制限的輸液/血管収縮薬、トラネキサム酸、 低体温是正、手術室直接搬入を重視。テロによる現場死亡 129 人。 多くは警察や救助隊到着前死亡で、頭部か胸部、または多部位 銃創によった。現場医療チーム判断で「1か所の穿通性胸部銃 創」と「腹部と下肢双方の銃創」を絶対緊急とし、5-8人を 1 グループにして地区ごとに事前に決められた計 18 病院に 356 人を搬送（AE76、RE226）。53人を受け入れたPitie Salpetriere 大学病院は、 23 人の手術適応例に対し 13 の手術室を飽和 させることなく最大 10 列稼働でDamage control surgeryを実 施。1 週間後死亡率 $1.3 \%$ 。今後本邦で同時多数穿通性外傷例 発生時の関連部門の対応の体系化を図るうえで、重要な情報と 考え報告する。

〈略歴〉

〈現職〉

横浜市立大学大学院医学研究科・医学部医学科 救急医学 主 任教授

帝京大学医学部救急医学講座 客員教授

神戸大学大学院医学研究科 非常勤講師

神奈川県立保健福祉大学 非常勤講師

〈学歴・職歴〉

横浜市立大学医学部卒業 (1986年)

日本医科大学付属病院救命救急センター (1989年)

横浜市立大学医学部附属浦舟病院救命救急センター（1990年） フランス院外救急医療支援組織 $(\mathrm{SAMU})$ パリ本部 留学 (1997 年)

国立横浜病院救命救急センター副センター長（2002年）

帝京大学医学部附属病院救命救急センター 講師 (2003年)

帝京大学医学部 救急医学講座 准教授 (2007年)

現職(2010年10月 1 日)

東京大学大学院医学系研究科客員教授（2016年 6 月 16 日）

〈所属学会・研究会委員等〉

日本救急医学会

·救急科専門医・指導医・評議員

・院外心停止例救命のための効果的救急医療体制・治療ス卜ラ テジの構築に関する学会主導研究推進委員会委員長

·教育・研修統括委員会委員長

日本臨床救急医学会

- 理事

緊急度判定体系のあり方に関する検討委員会委員長

日本集中治療医学会

専門医・評議員

日本外傷学会

- 理事

・専門医・評議員

日本集団災害医学会

理事

- Mass Gathering イベント医療検討委員会委員長

日本外傷診療研究機構

- 理事

〈行政関連〉

横浜市

- 横浜市救急医療検討委員会委員

·横浜市救急業務検討委員会委員

・横浜市メディカルコントロール協議会会長

・横浜市災害医療アドバイザー

神奈川県

神奈川県救急医療問題調查会委員

・神奈川県メディカルコントロール協議会委員

·神奈川県災害医療コーディネーター

○東京都

東京都メディカルコントロール協議会委員

·東京消防庁救急相談センター運営協議会委員・同救急相談医 医長 


\section{総会特別企画 $03-3$}

原発事故災害と小児甲状腺癌〜チェル ノブイリ事故の経験から考える福島県 に打ける甲状腺癌発症の現況と将来展 望〜

金地病院外科 11 , 日本医科大学内分泌 外科 ${ }^{2}$

清水一雄 1 ,2)

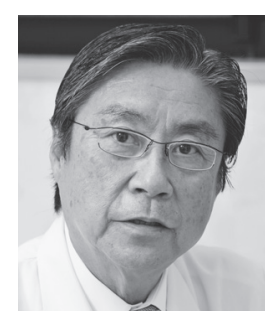

30 年前ソ連（現クライナ）で起こったチェルノブイリ原発事故後の放射能 污染は隣国現ベラルーシに小児甲状腺癌の大量発症をもたらした。一方、2011 年 3 月、東日本大震災直後に生じた福島原発事故の放射能污染は、チェルノブ イリ事故後急増した小児甲状腺癌を再び彷彿させた。福島県では同年10月よ り 18 歳以下の被災者 36 万人に対する甲状腺超音波検查を開始し、現在、当時 胎览を含めた 38 万人を対象に二巡目検査が進行中である。

一般的に $1-2 / 100,000$ 人と言われた稀な小児甲状腺癌は、チェルノブイリ 事故後約 $1 / 10,000$ 人となり、福島事故後細胞診検查で診断された「悪性また は悪性の疑い」は 167 人である。この数字から考えると福島原発事故後では明 らかに小児甲状腺癌が更に多く発症している。しかし、この結果をそのまま放 射能災害の影響による癌発症として結論づけるのは早計である。両事故を比較 してみると様々な背景因子の違いを考虑する必要があるからた。更に医学史上 類を見ない小児を対象とした大規模な系統的検査で得られた結果である事か ら、現在まで認められる現象は過去の検査結果にこだわる事なく新事実とて受 け止める必要がある。

本講演では、我々外科医のみならず広く一般社会で知っておか枚ばならない 放射能災害後に生じた小児甲状腺癌の現況と両事故の背景因子、将来に対する 展望と対応につき述べる。

〈略歴〉

昭和 23 年 4 月 22 日生まれ

昭和 48 年 8 月日本医科大学卒業

同年日本医科大学付属第 1 病院第 2 外科入局

昭和 55〜 57 年 米国ノースカロライナ州デューク大学外科留学

平成元年〜 2 年 米国ボストン、ハーバード大学ジョスリンクリニック、

平成 2 年本学第 2 外科講師 米国セントルイス、ワシントン大学外科へ留学

平成 8 年第 2 外科助教授

平成 11 年同教授

平成 15 年 日本医科大学外科学第 2 講座 (内分泌外科 · 心臓血管外科・呼吸 器外科) 主任教授・内分泌外科部長

平成 18 年 4 月 日本医科大学外科学講座（内分泌 - 心臓血管・呼吸器部門） 主任教授・内分泌外科部長

平成26年 $(2014$ 年) 3 月 31 日 日本医科大学定年退職

平成26年 (2014年) 4 月 1 日 日本医科大学名誉教授

平成26年 (2014年) 6 月 1 日 甲状腺病研究所 医療法人社団 金地病院名誉 院長

平成26年（2014年）10月 1 日 ベラルーシ医学再教育アカデミー 名誉博士

平成 27 年 $(2015$ 年) 10 月 1 日 日本医科大学特任教授

〈学会長〉

第 6 回アジア太平洋内分泌会議（Asian-Pacific Endocrine Conference）:

平成 5 (1993) 年 2 月 米国ハワイ州ホノルル市

第13回アジア太平洋内分泌会議（Asian-Pacific Endocrine Conference）:

平成 $12 （ 2000 ）$ 年 2 月 米国ハワイ州ホノルル市

第 5 回内視鏡下内分泌手術研究会 : 平成 14 (2002) 年 9 月 18 日 (水) 東京

第 13 回吊り上げ法手術研究会: 平成 15 (2003) 年 6 月 26 日-27日 東京

$16^{\text {th }}$ Asia Pacific Endocrine Conference (Congress Vice-president 2004年)

Ho Chimineh, Vietnam

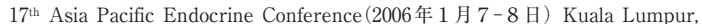
Malaysia

第39回日本甲状腺外科学会総会会長（2006年10月26-27日、東京)

$6^{\text {th }}$ Annual congress of GasLESS International 2007 (2007年12月 8 日 中国、 北京）

第 1 回大江戸内分泌手術手技懇話会（2,009年 4 月 18 日、日本医科大学橘桜木

ール)

$12^{\text {th }}$ Congress of Asian Association of Endocrine Surgeons(第12回アジア内 分泌外科学会学術集会) (2010年 3 月 22-23日、東京、京王プラザホテル) 第 23 回日本内分泌外科学会学術集会（2011年 7 月 7 日-7月 8 日、ホテルオー クラ東京)

第 823 回外科集談会当番世話人（2011年 12 月 10 日、東大山上会館 $)$

〈委員など〉

福島県「県民健康調査」検討委員会委員（～平成 29 年 7 月 9 日)

福島県「県民健康調査」検討委員会甲状腺専門家評価部会 部会長

〈資格など〉

日本外科学会専門医：平成 14 年 (2002年) 12 月 1 日 平成 29 年（2017年） 12 月 31 日

日本外科学会指導医

日本甲状腺学会専門医（認定番号：05021、期間 2005 年 7 月 1 日 2010年 6 月 30 日）

内分泌 ·甲状腺外科専門医（2009年 4 月 1 日 2013年 12 月 31 日） N09189号

日本内分泌外科学会名誉会員 (平成 26 年 5 月 )

日本甲状腺外科学会名誉会員 (平成 26 年 11 月 )

日本外科学会特別会員 (平成 26 年 4 月 2 日 )

日本内視鏡外科学会特別会員 (平成 26 年 11 月

日本臨床外日本外科学会特別会員（平成 26 年 4 月～)

\section{総会特別企画 04-1}

Liver Surgery in USA: Then and

Now

University of Pittsburgh, USA

David A. Geller

Liver surgery has evolved greatly over the past 50 years. Dr. Starzl performed the world's first human

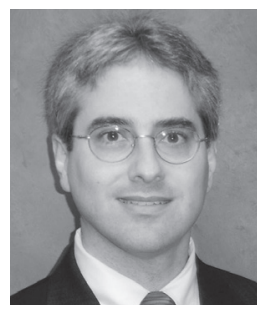

liver transplant in Denver, Colorado, USA in 1963. Since that time, we have seen dramatic improvement in liver resection and liver transplantation techniques and outcomes. Laparoscopic liver resection (LLR) has been growing in number and complexity, with the nearly 10,000 cases published worldwide. Numerous studies have shown short-term patients benefits for laparoscopic liver resection that include less post-operative pain, decreased morbidity, and shorter hospital length of stay. Importantly, the long-term oncologic outcomes for laparoscopic liver resection for hepatocellular carcinoma (HCC) and metastatic colorectal cancer (mCRC) have been shown to be comparable when compared to open resection. Recent studies have also demonstrated that laparoscopic major hepatectomy can be safely accomplished by high volume centers experienced in laparoscopic liver resection. Current data on laparoscopic liver resection will be summarized.

〈Profile〉

Dr. Geller is the Richard L. Simmons Professor of Surgery at the University of Pittsburgh School of Medicine. He serves as Chief of the Division of Hepatobiliary and Pancreatic Surgery, and Director of the UPMC Liver Cancer Center. Clinically, he specializes in laparoscopic liver resection surgery. Dr. Geller and his partners have performed over 800 minimally invasive liver resections which is one of the largest experiences in the world. His research interests include molecular mechanisms of hepatic ischemia/ reperfusion injury, and liver cancer cell biology. Dr. Geller is a member of many professional societies including the Society of University Surgeons (President 2009-2010), American Surgical Association, American Society of Transplant Surgeons, Society of Surgical Oncology, AHPBA, IHPBA, SSAT, and the American Society of Clinical Investigation. Dr. Geller has published 300 scientific papers and chapters, and has presented at more than 390 meetings or seminars. He has active research funding from the NIH for the past 20 years, and is also the Principal Investigator on industry-sponsored clinical trials for liver cancer and liver surgery. 


\section{総会特別企画 04-2}

Liver Surgery in France

Hepatobiliary Center - Paul Brousse

Hospital, France

Daniel Cherqui

There has been a long tradition of Liver Surgery (LS) in France. This goes back to Couinaud who published in 1957 a

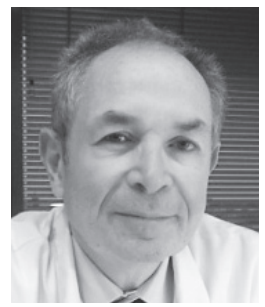

comprehensive study of liver anatomy. He described the 8 liver segments, fed by individual inflow portal triads covered by individual sheaths, and the boundaries formed by the outflow main hepatic veins defining sectors and right and left livers. This classification, although refined over the years, is still used today and is the base of modern LS. The French school of LS started with Hepp and Lortat Jacob but Henri Bismuth was the first in France, in 1971, to organize and envision LS as a speciality, in fact Hepatobiliary Surgery (HBS). He trained several surgeons who in turn trained others and most University Hospitals developed a program of HBS. Pancreatic surgery was later associated to form HPB Surgery as in other Countries. In France, Liver Transplantation from deceased donors started in the 70s also pioneered by Henri Bismuth's group. As a consequence, Liver Transplantation has always been associated with LS, in an organ-oriented specialty, rather than a specialty of Transplant Surgery that does not really exists in our country. Urologists together with nephrologists perform kidney transplantation.

In France, access to Residency is based on a National Competing Exam taken in 6 th year of studies. Residents can then choose their geographic affiliation and specialty according to their ranking at this exam.. Hepatobiliary surgeons come from General/Digestive Surgery training. After a 5 -year residency, giving access to Board Certification, surgeons complete their training with a 2 -year fellowship in a sub-specialty Unit. After fellowship, they can be appointed locally but usually have to find a job at another institution.

National Ministry of Health statistics for years 2007-2010 show that 7,500 liver resections in 500 hospitals are performed per year for an annual incidence of $13 / 105$ population which is higher than reported North American data. Cases range between 1 and 250 cases per year (median 4/y) with 280 and 13 centers performing $>50$ and $>100$ cases/y, respectively. Laparoscopic surgery represented $17 \%$ of all liver resection in 2007-2012.There are 24 active liver transplantation centers, all associated with an HPB program performing approximately 1,200 cases a year. Major resections ( 3 or more segments) account for $35 \%$. Indications include secondary ( $>90 \%$ colorectal) and primary liver cancer (HCC and Cholangio) in 51 and $23 \%$, respectively. Benign conditions and unknown diagnosis account for 12 and $14 \%$, respectively. Larger centers perform more major resections and operate on most primary cancer cases. In-hospital and 90 -day mortality rates are 3.2 and $5.1 \%$, respectively. Mortality is increased with comorbidities, indication of primary cancer, major resection, associated procedure, volume $<11$ cases/y and non-tertiary care center.

Our Center, founded by Henri Bismuth, is the largest Liver Unit in France with approximately 250 resections and 130 Transplants per year. Mortality after resection is $2.7 \%(2010-2015)$ and survival after transplantation is $92,85,71$ and $58 \%$ at 3 months, 1,5 and 10 years, respectively (2000-2015)

\section{〈Profile〉}

Prof. Daniel Cherqui is currently Professor of Surgery at Université Paris-Sud and Surgical Director of Liver Transplantation at Paul Brousse Hospital in Villejuif-Paris France. He is an internationally renowned expert in liver transplantation and liver resection. He has published extensively and is considered one of the pioneers of laparoscopic liver surgery. Prof. Cherqui received his surgical training at the University of Paris and completed a liver transplant fellowship in Prof. Henri Bismuth's Unit in 1986 and at the University of Chicago in Prof Christoph Broelsch's Unit in 1987. In 1988, he was recruited to start a Liver Transplantation and HPB Surgery Program at Henri Mondor Hospital in Créteil-Paris where he became Chairman of General Surgery in 2005. In 2010, he moved to Weil Cornell Medical Center in New York, NY USA, as Chief of HPB Surgery and Liver Transplantation. In 2013, he moved back to France and joined Paul Brousse Hospital, home of the largest liver transplant program in France.

\section{総会特別企画 04-3}

Liver Surgery in Japan

Hepato-Biliary-Pancreatic Surgery

Division, Department of Surgery,

Graduate School of Medicine, The

University of Tokyo

Norihiro Kokudo

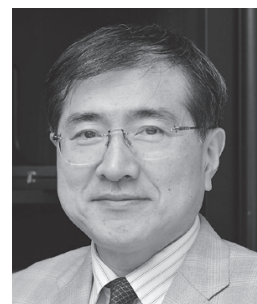

Since 1980's, there have been a number of significant achievements in Japanese liver surgery, including intraoperative ultrasound (IOUS), operative safety criteria based on indocyanine green (ICG) test, concept of anatomic segmentectomy or parenchymal preserving approach, and preoperative portal vein embolization. Operative mortality after liver resection has been dramatically improved from over $15 \%$ in 1970 's to around $1 \%$ after 2000 in Japanese tertiary centers. Recent advances in surgical technique are preoperative 3 -D simulation and navigation surgery using ICG fluorescence. The former is covered by social medical insurance since 2012 in Japan.

Current indications of liver resection for hepatocellular carcinoma (HCC) are: Child-Pugh A, B, within ICG-based criteria (so called Makuuchi criteria), 3 or less tumors with no size limitations. According to the most recent nationwide survey, 5 -yr overall survival of all resectable patients was $56.8 \%(n=20,866)$. More favorable outcome can be expected among patients with single, $5 \mathrm{~cm}$ or smaller tumors without vascular invasion. A head to head multicenter randomized controlled trial (RCT) comparing liver resection vs. radiofrequency ablation for small HCCs (SURF trial) is ongoing. Presence of vascular invasion has been regarded as one of the poorest patient subgroups carrying little chance for cure. However, recent propensity score matched analysis using nation wide survey data revealed significant survival benefit for liver resection even for patients with vascular invasion.

Aggressive surgery for multiple bilobar colorectal liver metastases has been tried in many Japanese centers since 1990's. Japanese approach of parenchymal preservation has advantages of operative safety and better chance for repeated resections. This concept has gradually been accepted in Western countries. Since there has not yet been sufficient evidence to support benefit of perioperative chemotherapy, upfront surgery for resectable disease is a daily practice in Japan. Recently, a RCT testing the benefit of adjuvant oral uraciltegafur with leucovorin after curative liver resection was positive in prolonging RFS.

The first laparoscopic liver resection in Japan was performed by Professor Hironori Kaneko in 1993 and it has gradually gained popularity. The second International Consensus Conference on Laparoscopic Liver Resection 2014 held in Morioka was a great success and it produced a position paper including recommendations regarding surgical indications, preoperative evaluation, bleeding controls, transection methods, anatomic approaches, and equipment. Since April 2016, laparoscopic major heaptectomies have been covered by social medical insurance with a condition of mandatory prospective preoperative national registry.

$\langle$ Profile〉

Dr. Norihiro Kokudo is the professor and chairman at Hepato-Biliary-Pancreatic Surgery Division and Artificial Organ and Transplantation Division, Department of Surgery, The University of Tokyo Hospital. He earned his M.D. in 1981, and then Ph.D. in 1988 at University of Tokyo. From 1989 to 1991 he stayed at Department of Surgery, University of Michigan as a visiting research investigator. After 6 years at Cancer Institute Hospital, Tokyo, as a senior staff of GI surgery, he joined the current institution as an associate professor in 2001. He then rose to the current position in 2007. Dr. Kokudo has been conducting a number of research projects on surgical treatment of HCC, colorectal liver metastases, and living donor liver transplantation. As the chairman of the guideline committee, he compiled $3 \mathrm{rd}$ version of Japanese clinical practice guidelines for HCC in 2013. Dr. Kokudo is the immediate past president of Japan Surgical Society and is currently the president of Asian-Pacific Hepato-Pancreato-Biliary Association (A-PHPBA). He is the secretary general of International Hepato-Pancreato-Biliary Association (IHPBA), and a governing board member for ILCA. He is also a fellow of American College of Surgeons and Royal College of Surgeons of England, and a member of International Society of Surgery and The Society of Surgical Oncology. He is an honorary regional editor for $\mathrm{HPB}$, and an associate editor for Liver Cancer and Japanese Journal of Clinical Oncology. He is on the editorial board of Annals of Surgery, Surgery, World Journal of Surgery, and Journal of HPB Science. 


\section{総会特別企画 05-基調講演}

新たな専門医制度の現状と課題

一般社団法人日本専門医機構

吉村博邦

日本専門医機構では、平成 29 年 4 月 の新たな専門医制度のスタートを目指 して準備を進めて来たが、本年 2 月に 至り、国の社会保障審議会医療部会に

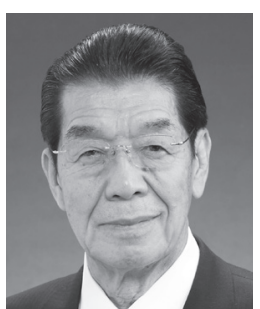

おいて、基幹施設の認定基準が厳し過ぎること、募集定員が過 去の実績の $2 \sim 3$ 倍で専攻医の大都市集中が加速する怖れがあ ること、さらに、機構のガバナンス不足なども指摘されるに至 り、かかる状況の中、本年 6 月役員の改選があり、ほぼオール ジャパンの理事会体制が構築されることとなった。新理事会で は、来年度からの研修開始を 1 年延期し、再来年度に基本 19 領域で一斉にスタートすることを目指すことを決定した。また 基本的な姿勢として、1.機構と学会が連携して専門医制度を 構築する、2.機構と学会の役割分担の明確化を図り、学会は、 学術的な観点から責任をもって研修プログラムを作成する、 3.機構の役割について、(ア) 専門医制度を学術的な観点から 標準化を図り、領域学会に対し、チェック機能、調整機能を発 揮し、領域学会をサポートする。(イ) 専門医を公の資格とし て認証する。(ウ) 専門医に関するデータベースを各領域学会 と共同で作成する。（エ）専門医制度を通して、国民に信頼さ れる良質な医療を提供するための諸施策を検討する、などを定 めた。国民の視点に立って、専門医の在り方に関する検討会の 報告書の趣旨を踏まえ、国民から信頼される質の高い医療を提 供できる専門医の育成と認定を目指して、最大限の努力を尽く す所存である。

〈略歴〉

生年月日（年齢）：昭和 16 年 11 月 28 日生（74歳）

昭和 35 年 3 月 鳥取県立鳥取西高等学校卒業

昭和 35 年 4 月 東京大学教養学部理科 II 類入学

昭和 41 年 3 月 東京大学医学部卒業

昭和 42 年 4 月 東京大学第二外科研修医

昭和 48 年 10 月＼cjkstart北里大学医学部胸部外科学講師

昭和 56 年 10 月 (同上)

助教授

昭和 57 年 3 月

米国テキサス州立大学 MDアンダーソン癌 センター准教授

(昭和 58 年 5 月帰国)

平成 6 年 5 月

平成 14 年 7 月

平成 19 年 3 月

北里大学医学部胸部外科学主任教授

北里大学医学部長

平成 20 年 3 月

定年退職、北里大学名誉教授

公益社団法人地域医療振興協会顧問として 現在に至る。

〈その他役職〉

全国医学部長病院長会議・監事（元会長）

私立医科大学協会・参与 (元副会長)

日本専門医機構・理事長（平成 28 年 7 月～)

〈学会等〉

世界肺がん学会名誉会員

世界気管支学会名誉会長

米国胸部疾患学会フェロー会員

日本外科学会特別会員

日本胸部外科学会名誉会員

日本呼吸器外科学会名誉会員

日本呼吸器内視鏡学会名誉会員

日本内視鏡外科学会特別会員

日本外科系連合学会特別会員
昭和 45 年 7 月 財団法人結核予防会結核研究所外科（医員
総会特別企画 06-コメンテーター

膳場貴子

TBS系列「報道特集」(土曜 $17: 30)$ キャスター。

大学で健康科学・看護学を専攻後、 97

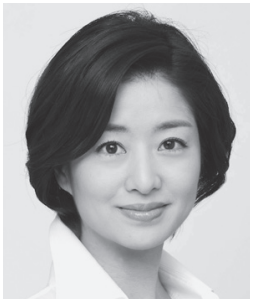

「おはよう日本」「プロジェクトX」「紅白歌合戦司会」などを 担当後、退職。

'06 年から今年 3 月までTBS「NEWS23」キャスターを務める。 昨年出産、一女の母。 
総会特別企画 $06-1$

育児休業取得の経験を踏まえて〜真の

ワークライフバランスの実現に向けて

$\sim$

環境省（前厚生労働省）

井筒将斗

少子化対策の観点から、契緊の課題

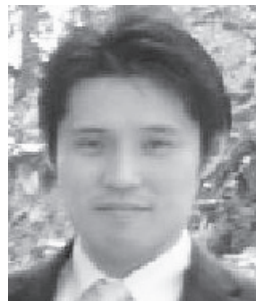
となっている仕事と子育ての両立支援

などを一層進めるため、男女ともに子育て等をしながら働き続 けることができる雇用環境を整備することなどを目的に平成 21 年 6 月に育児・介護休業法が改正された。育児休業制度の 見直しに合わせて、男性が積極的に育児に関わることができる 一大ムーブメントを巻き起こすことを目的に、「イクメンプロ ジェクト」が立ち上げられ、様々な取り組みが行われていると ころである。国家公務員（常勤職員）においても、男性職員 の育児休業取得率は平成 21 年の $1.6 \%$ から、平成 26 年には、 5.5 $\%$ と増加傾向を示しており、特に厚生労働省の男性職員の平成 26 年の取得率は $13.8 \%$ と他省庁と比較すると高い水準を示して いる。本セッションでは、育巟休業に関する諸デー夕、霞ヶ関・ 地方自治体における取り組みなどを紹介し、その上で、国家公 務員である著者が男性の立場で育児休業を取得した経験を入省 前の育児に関する状況と比較しながら報告する。

\section{〈略歴〉}

平成 21 年 3 月 岡山大学医学部医学科卒業

平成 21 年 4 月 岡山大学大学院疫学 ·衛生学分野博士課程 岡山大学病院初期臨床研修医

平成 23 年 4 月 岡山済生会総合病院外科医員

平成 25 年 12 月 岡山大学大学院疫学・衛生学分野 助教

平成 26 年 4 月 厚生労働省入省 医政局総務課医療安全推進 室

平成 27 年 4 月 厚生労働省大臣官房統計情報部人口動態 · 保 健社会統計課保健統計室

平成 28 年 9 月 環境省総合環境政策局環境保健部環境保健企 画管理課特殊疾病対策室
総会特別企画 06-2

女性医師支援の現状と今後の課題

日本医師会

道永麻里

我が国の医師国家試験合格者に占め る女性の割合は、平成 12 年以来 3 割 を超え、それに伴い女性医師数は年々 増加している。また、女性医師の就業

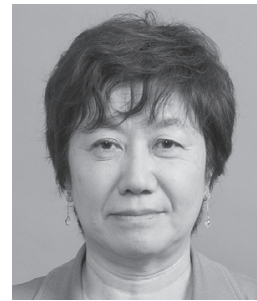
率は、女性全体の就業率と同様、30歳代に大きく凹む、いわ ゆる $\mathrm{M}$ 字カーブを形成し、妊娠・出産・育児により離職する 女性医師の存在が取り沙汰されてきた。現在、国や地方では、 復職支援や育児支援、勤務環境の整備などの女性医師への支援 が行われ、少しずつ成果が具現化されてきた。しかし、一般社 会のみならず、医師の世界における男女共同参画、とりわけ意 思決定の場への女性医師の参画については、未だ十分な成果を 得ない状況にある。日本医師会は、会内に「女性会員懇談会」(平 成 $10 \sim 13$ 年度、平成 $16 \cdot 17$ 年度) や「男女共同参画委員会」(平 成 18 年度〜）を設置し、早くから女性医師に関わる取り組み を行ってきた。平成18年度からは、厚生労働省の委託を受け、 女性医師バンクを中心とした「医師再就業支援事業」を開始し、 平成 21 年度に「女性医師支援センター事業」と名称を改め、 勤務継続支援に重点を置いた女性医師支援の取り組みを推進し てきた。日本医師会は、これまでの活動や調査結果に基づく女 性医師の現状を踏まえ、女性医師のさらなる活躍を図るために、 「医師全体の勤務環境の改善」と、「指導的立場、意思決定機関 への女性の参画」が重要な課題であると考え、女性医師支援に 関する施策のさらなる強化に努めている。

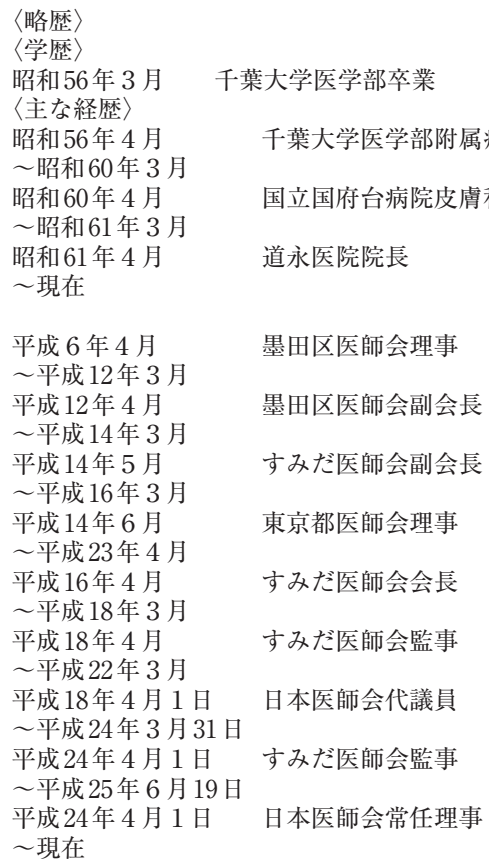




\section{総会特別企画 $06-3$}

秋田大学医学部におけるキャリア教育 とイクボス宣言

秋田大学 総合地域医療推進学講座 蓮沼直子

近年、女性医師支援の流れは確固とし たものとなり、復職支援から継続支援、

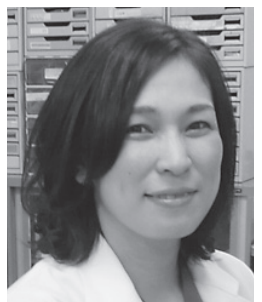
そして活躍支援へとシフトしてきてい

る。また、ワークライフバランス (WLB) についての男性医 師の意識や価值観の変化も出てきたように感じる。女性医師が 子育てしながら活躍するためには、本人の意識の醸成や勤務環 境整備、配偶者も一緒に子育てや家庭運営をしていく家庭にお ける男女共同参画も必要である。今後は育児のみならず健康問 題や介護等で時間制約のある医師も増えることが予想されるこ とや、同僚として一緒に働いていくことからも、男女ともキャ リアについて考え、学んでおく必要がある。

そこで秋田大学医学部では 2009 年より必修講義として 1 年生 と 3 年生でキャリア教育を取り入れてきた。そこでは 1 .医師 として将来のビジョンを考える。2.自分自身や価值観につい て考える。3.多様なキャリアパスや様々な継続支援について 知る。4.参加型講義で、シナリオを使ったグループディスカ ッションを通して、考え方の多様性や、キャリアに正解はない ことを感じる経験をする。5.ロールモデルの経験談を聞く。 6 . 将来のライフイベントを考慮しキャリア未来年表を作成す る。などを経験・行動目標にしている。

ここでは、秋田大学で行っているキャリア教育の詳細と女性医 師活躍の key personであるイクボスについて紹介する。

〈略歴〉

1994年 3 月 秋田大学医学部医学科卒業

〈職歴〉

1994年 5 月 秋田大学医学部皮膚科 医員

1996年 4 月 秋田大学医学部皮膚科 助手

1997年 1 月 National Institutes of Health, NCI

～1999年 9 月

2003 年 10 月 東北大学医学部皮膚科 大学院研究生

2004 年 8 月 秋田大学医学部感覚器学講座皮膚科学 - 形成外科 学分野 医員

2007 年 4 月 秋田大学医学部感覚器学講座皮膚科学 - 形成外科 学分野 助教

2009年 4 月 秋田大学医学部総合地域医療推進学講座 助教

2013年 10 月 秋田大学医学部総合地域医療推進学講座 准教授

2013年～＼cjkstart愛媛大学医学部非常勤講師

2016年＼cjkstart熊本大学医学部非常勤講師

2016年＼cjkstart東京医科大学非常勤講師

2016年＼cjkstart福島県立医科大学非常勤講師

〈資格〉

医学博士

日本皮膚科学会専門医、日本皮膚臨床外科学会専門医、日本抗 加齢医学会専門医、医療メデイエーターB

米国NLP協会認定トレーナー、認定コーチ

株式会社ワークライフバランス 認定ワーク・ライフ・バラン

スコンサルタント

マインドマップ アドバンスプラクティショナー

〈その他〉

秋田県医師会女性医師委員会 委員長 (2010年〜 )

秋田県男女共同参画審議会委員（2010年～、2015年より会長）

日本皮膚科学会 皮膚科の女性医師を考える会委員（2011 2014年、現キャリア支援委員会）2016年～東部支部協力委員 日本皮膚科学会 皮膚科リーダー養成WS WG委員（2014年 $\sim)$

日本皮膚科学会 サマースクールWG委員 (2015年〜)

医学教育学会 生涯・キャリア教育委員会委員（2016年～)

〈賞罰〉

第 71 回日本皮膚科学会東部支部学術大会 大会会長賞

平成 26 年度秋田県男女共同参画社会づくり表彰ハーモニー賞
総会特別企画 $06-4$

ワーキングマザーの外科医の立場から

見えたこと

国立国際医療研究センター 外科

野原京子, 山下智, 相馬大介, 杉浦良子,

徳原真, 枝元良広, 安田秀光, 山田和彦,

橋本政典，矢野秀朗

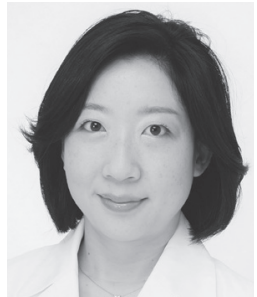

外科医が不足している昨今において女性外科医は徐々に増加し ている。その反面、女性が外科医として働き続けるには課題も 多い。私も卒後 12 年目に出産を経験しどのように外科医を続 けるのかを考える節目を迎えた。女性活躍促進が謳われる時代 の恩恵も受けて世の中の多様な働き方を知ることもできた。た だ、外科医が一般の職業と大きく異なる点は命をダイレクトに 預かっているところにあると考えている。侵襲的な治療である 故の責任の重さは経験した者にしか分からないかもしれないと さえ思う。更に高齢者、ハイリスク患者が増加し経過が必ずし も安定しているとは限らない。幼い子供をもちながら 24 時間 体制で対応する事は困難を極め、手術を離れる事を選択する方 法もあるであろう。私は上部消化管に携り鏡視下手術の領域は 手術指導全般の任務を頂戴している。この両立の鍵は何よりも 家庭の事情で負担をかけてしまう際に快く送り出して下さるチ ームのメンバーであり、急に帰宅が遅くなった時にも機嫌よく 待っていてくれる家族である。今感じるのは、周囲の理解で生 まれる安心感は次の挑戦を生む原動力になり、何とかして還元 したいという気持ちを強くさせる。組織は双方向の助け合いが なくては成り立たず、その形は多様であっていいはずである。 それが自然に広く受け入れられる未来の一助になれるよう模索 しながら研鑽を積んでいきたいと思っている。

〈略歴〉

2002 年 東京慈恵会医科大学医学部卒業

2002 年 NTT東日本関東病院 レジデント、後期レジデント

2007 年 がん研有明病院 消化器センター外科 シニアレジ デント

2011年 NTT東日本関東病院 外科スタッフ

2015年 国立国際医療研究センター 外科スタッフ

日本内視鏡外科学会技術認定医（胃） 


\section{総会特別企画 $06-5$}

女性外科医と共に働く環境作り〜男性

医師も含めたワークライフバランスの

改善へ〜

高梘赤十字病院 消化器外科・乳腺外 科

今井義朗, 平松昌子, 小林稔弘,

恒松一郎, 河野恵美子, 高野義章,

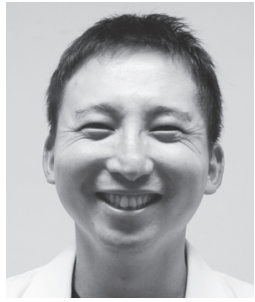

前沢早紀

女性外科医支援とは女性外科医の外科職務継続だけが目的では なく、将来外科の重要な担い手として活躍してもらう事も重要 である。当院では消化器・乳腺外科の医師 7 名中 3 名が女性医 師であり、うち 2 名は演者の指導医の立場にある。また演者の 配偶者も外科系女性医師であり、一般よりも多くの女性外科医 に囲まれた環境で仕事をしていると思われる。指導医の 1 名は 学童期の子供を持ち、妻は 5 歳児、 2 歳児の子育てをしながら、 いずれもフルタイムでの勤務を継続中である。育児に伴う当直 免除や時間外勤務軽隇制度はあるが、現在はいずれもオンコー ルや休日出勤、当直も一部こなしている。上司の女性外科医 1 名は管理職でもあり育児支援には積極的である一方、過度の勤 務制限は女性外科医の経験不足につながる可能性も危惧される ため、病览保育や時間外保育制度を充実させつつ緊急手術や時 間外勤務にも携われる環境作りに力を入れている。また女性外 科医の育児支援として配偶者の協力は必要不可欠であり、当科 では男性外科医のイクメン活動に対しても非常に理解を頂いて いる。女性外科医を優遇し男性外科医の負担を強要するのでは なく、男性外科医も含めて仕事と家庭の両立を目指している。 上司が女性外科医だから提言できる事も多く、男性外科医も協 カしやすくスタッフ全員のまとまりも感じる。個々の問題点を 話し合い、男女を問わずスタッフ全員がwin-winになれる環 境作りが大切である。

\section{〈略歴〉}

平成 19 年 3 月 大阪医科大学医学部医学科卒業

平成 19 年 4 月 大阪医科大学附属病院 研修医

平成 21 年 4 月 大阪医科大学一般・消化器外科 入局

平成 22 年 4 月 大阪医科大学大学院医学研究科博士課程入学

平成 22 年 4 月 市立枚方市民病院 外科勤務

平成 25 年 4 月 大阪医科大学一般・消化器外科 レジデント

平成 26 年 3 月 大阪医科大学大学院医学研究科博士課程修了 医学博士

平成 26 年 4 月 大阪医科大学救急医療部 助教

平成 28 年 4 月 高柣赤十字病院消化器外科 医院

\section{総会特別企画 06-6}

継続から活躍へ一女性外科医がキャリ アを形成できる外科をめざして一 関東中央病院 外科 河原正樹

女性医師の現状は、厚生労働省のデー 夕によれば、医師国家試験合格者の $31 \%$ 、医療施設従事医師の $20 \%$ が女性

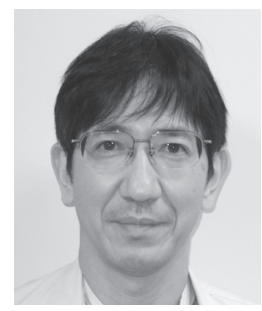
医師の占める割合である。外科においては、全体の志望者は減 少しているが、その中で女性外科医は増加している。こうした 現状のもとで外科を活性化するためには、男女共同参画を推進 し、女性医師を含めた外科医師全体の就労環境を見直すことが 必要である。すなわち、女性外科医が就労を継続し、発展的に キャリアを形成できる外科にすることが、男性も含めた外科医 師全体の勤務環境を改善することにつながると認識すべきであ る。ライフイベントを有する女性外科医が就労を継続するため には、家庭と職場の理解と支援、就労環境の整備が必要である。 特に、労務環境の改善策として、当直の免除、短時間勤務、千 一ム医療による個人負担の軽隇等が必要となるが、このために は常勤マンパワーの確保が必要で、病院の組織的な支援を引き 出すことが必要かつ重要である。また、女性医師が活躍できる 環境作りには、組織として支援する体制があり、活躍の場が提 供され、よきロールモデルが存在し、将来のキャリアパスが明 るいビジョンを持って描かれなくてはならない。そのためには、 どのような施策が有効なのか、当院での取り組みについてその 一端を紹介するとともに、女性外科医をパートナーに持つ一外 科医として、家庭での協力体制、仕事・育児における価值観の 共有等について述べてみたい。

\section{〈略歴〉}

1982年 山形大学医学部卒業

1982年 東京大学医学部第三外科研修医

1986年 都立駒込病院外科医員

1988 年 東京大学医学部第 3 外科助手

1990年 Fellow, St. Vincent's Hospital (Melbourne, Australia)

1991 年 東京大学第 3 外科助手

1992年 友愛記念病院外科医長

1994年 公立昭和病院外科医長

1998年 東京大学医学部消化管外科講師

2002 年 横須賀共済病院外科部長代行

2003年 公立昭和病院外科医長 東京大学消化管外科非常勤講師

2005 年 公立学校共済組合 関東中央病院 外科部長 2010 年 公立学校共済組合 関東中央病院 副院長 現在に至る

〈資格〉

医学博士 (東京大学)

日本外科学会専門医、指導医

日本消化器外科学会専門医、指導医

日本消化器内視鏡学会専門医、指導医

日本大腸肛門学会専門医、指導医

日本がん治療認定医機構暫定教育医

日本臨床外科学会 評議員

世田谷区がん対策検討委員会委員 


\section{総会特別企画 06-7}

女性医学生が増える今一消化器外科医 としてともに働く環境作りのために一 岩手医科大学 外科

大塚幸喜，木村聡元，箱崎将規，

八重樫瑞典, 上嶋徳, 三宅孝典,

高原武志, 秋山有史, 岩谷岳, 新田浩幸,

肥田圭介, 佐々木章

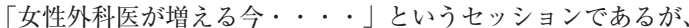
現在女性消化器外科医の少ない施設から、当教室の現状と女性 医師が入局を阻む原因についてアンケート調査を行ったのでそ の結果を、医局長という立場から報告する。当大学医学部は現 在、一学年の定員数は 120 名で、約 40 名（30 35\%）が女子学 生である。また、女子学生約 40 名中、約 10 名（20 25\%）は 県内出身者であるが、卒後県内で研修する女性はわずか 4 ～ 8 名である。5 学年には臨床実習がはじまり、外科では手術・病 棟・外来実習を中心に指導を行い、実習後のレポートにおいて は高評価を得ていると自負している。その結果、6 学年前半に 行われる選択による高度臨床実習においては、外科は前期、後 期ともに15名と、ここ数年人気講座となっている。また、医 局説明会は年 2 回開催し、医局員との交流も積極的に行ってい る。しかし、2006年からの女性入局者はこれまで計 6 名であり、 現在関連施設 3 名 (消化器外科 2 名、小览外科 1 名)、大学医 局 1 名 (乳線)、大学院 1 名 (消化器外科希望)、退局 1 名で、 大学医局員 34 名中、女性消化器外科医は不在である。この現 状を踏まえ、消化器外科入局を阻む原因を、 5 学年と 6 学年の 女子学生を対象にアンケート調査を行った。また、当院の複数 の外科系講座の医局長に対し、女性医師に対する医局としての サポート体制についてアンケート調査を行ったのでそれら結果 を報告する。

〈略歴〉

生年月日 S42.4.12 49 歳

〈学歴〉

1988年 岩手医科大学医学部入学

1993年 岩手医科大学医学部卒業

1993年 岩手医科大学第一外科入局 医員

2001年 岩手医科大学第一外科 助手

2001 年 大阪医科大学一般 - 消化器外科に国内留学 (腹腔鏡 下大腸手術)

2007 年 岩手医科大学 外科 講師

2016年 4 月 同特任准教授（現在に至る）

〈学位〉

1999年 医学博士取得

「食道癌術後早期の経腸栄養の有用性に関する検討」 〈学会資格〉

日本消化器外科学会雑誌 第 31 卷 第 4 号

日本外科学会 : 認定医・専門医・指導医

日本消化器外科学会: 認定医. 専門医・指導医

日本大腸肛門病学会 : 専門医・指導医

日本内視鏡外科学会 : 技術認定医

日本がん治療認定医

日本ストーマ・排泄リハビリテーション学会 : 認定士

〈評議員〉

日本内視鏡外科学会

日本ストーマ・排泄リハビリテーション学会

〈受賞〉

2001 年日本内視鏡外科学会カール・ストルツ賞受賞（最優秀 ビデオ)

2003年日本内視鏡外科学会伊藤賞受賞（最優秀論文）
総会特別企画 $06-8$

女性外科医が増える今、大学ができる こと

順天堂大学医学部乳腺 · 内分泌外科 齊藤光江

【はじめに】昨今、外科医不足、大学離れ等、 外科の将来は決して明るいとは言えない。 一方女性外科医は増加しているものの、 離職、管理職数不足等が課題である。大

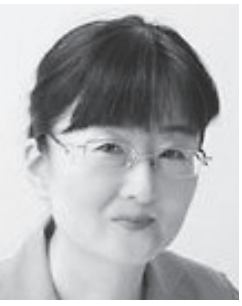
学で教育・研究・診療に携わる立場上、現状を踏まえて提言をしてみ たい。【現状】我々の教室で常勤を経験した36名の外科医の内訳は、 男性 13名 (36\%) 女性 23 名 (64\%)。40歳以上の割合は、男性 $84 \%$ 、 女性 30\%。学位取得者は男性 9/13（69\%）、女性 14/23（60\%）である。 出産経験者は 13 名で、うち出産・育児・介護等で 12 週以上の休職も しくは常勤職を降りた経験がある者は 12 名、1 年以上休職中の者は 1 名であった。復帰形態は大学常勤 2 名、大学院 2 名、関連病院常勤 1 名、開業 1 名、非常勤で研究 3 名、非常勤で診療 2 名と多様性が特 微である。取り組风】本人が望ま奴限り、ライフイベントを理由に 常勤職を解くことはないが、不公平感を招か奴に、幾つかの規則 を設けている。男女を問わず、学位と専門医取得を奨励し、各々のキ ヤリア構築ができるよう定期的な面談等を通じて支援している。提 言】男女とも早期から基礎的な能力獲得と目標の明確化を心掛け、自 己や周囲のライフイベントにしなやかに対処し、他人との比較ではな く、自身の描くロードマップと現状を比較して研鑚を積む姿勢を奖励 する教育と個々の目標に応じた適正な評価が肝要である。

〈略歴〉

〈職歴〉

1984年 3 月 千葉大学医学部卒業

1984年 6 月 東京大学医学部附属病院分院外科（研修医）

1986年 1 月 青梅市立総合病院外科（研修医）

1988年 1 月 東京大学医学部附属病院分院外科（研修医）

1990年 1 月 米国留学のため休職

(テキサス大学医学部附属 MDアンダーソン癌センター 細胞生物学ポスドク；Dr,J,Fidler，Dr,L,B,lachmanに師 事.

1992年 1 月 帰国。東京大学医学部附属病院分院外科 (助手)

1995年 10 月 財団法人癌研究会附属病院乳腺外科（嘱託医員）

1996年 6 月 東京大学より医学博士の学位を取得

(転移性肺癌に対するサイトカインの抗腫瘍効果の研究)

1999年 4 月 財団法人癌研究会附属病院乳腺外科 (医員)

1999年11月 日本乳癌学会専門医

2000 年 7 月 癌研究会研究所遺伝子診断研究部研究員（三木義男部長 に師事) 兼任

2002 年 7 月 東京大学大学院医学系研究科臟器病態外科学代謝栄養内 分泌外科 (講師)

2006 年 1 月 東京大学大学院医学系研究科臟器病態外科学代謝栄養内 分泌外科退職

2006 年 2 月 順天堂大学医学部乳腺内分泌外科助教授（後に呼称変 更 ; 先任准教授)

順天堂大学医学部附属順天堂医院乳腺科診療科長就任

2007 年 4 月 -5 月 米国短期研修 (MD アンダーソン癌センター附属 病院)

2012 年 7 月 順天堂大学大学院医学研究科乳腺 - 内分泌外科 教授就 任

2013年 3 月 中央大学大学院経営戦略科卒業 MBA 取得 現在に至る。

〈先行領域〉乳腺疾患の診断と治療、化学療法における支持療法と QOL

〈学会活動〉日本外科学会専門医、日本乳癌学会専門医、指導医 日本乳癌学会評議員、国際支持療法学会 (MASCC) 制 叶剤ガイドライン作成委員 (2009-)、日本癌治療学会制叶 剤ガイドライン作成評価委員委員長 (2010-)、日本外科学 会教育委員会委員、日本外科学会ヶースレポート誌編集 委員会委員、日本乳癌学会専門医制度委員会委員、同学 会男女共同参画委員会委員、日本乳癌オンコプラスティ ックサージャリー学会評議員、日本がんサポーティブケ ア学会理事、同学会ガイドライン委員会委員長

〈研究活動、研究推進活動〉文科省私学研究基盤助成金審查委員 (2013-2015)

AVON女性文化委員 (2006-)

日本乳癌学会班研究下妻班班員、

厚労省労働局労働疾病研究横山班班員 (2015-) 放射線医学研究所重粒子線臨床研究乳がん班 会議班長 $(-2015)$

〈国際貢献〉モンゴル、フィリビン、台湾、インドネシアからの留学 生受け入れ

モンゴル、フィリピン、タイでの乳がん啓発活動（医療者、 患者)

〈社会貢献〉災害時医療を考える会、御茶ノ水駅バリアフリー運動署 名活動、若年者乳癌の会ひろば創始、乳がん高校講座（千 葉県立松尾高校) 
総会特別企画 07-1

平成 28 年診療報酬改定について一臨

床外科を中心に一

厚生労働省保険局医療課

國光文乃

平成 28 年診療報酬改定では、医療機 能の分化・連携の推進、イノベーショ ン・アウトカムの適切な評価の観点を

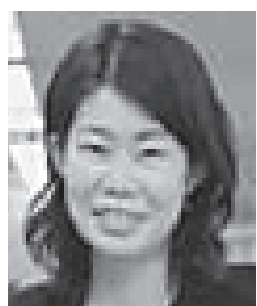

踏まえ、学会等からの提案書や外保連試案等を通じ、中医協に て検討を行い、様々な評価を行ったところである。

また、医療技術の進歩により、生存年や QOLなどアウトカム の向上が期待される一方で、医療財政への影響も懸念されてお り、今後益々、医療技術の適切な評価が求められる。

イノベーションの適切な評価と医療保険制度の持続可能性に向 け、平成 28 年診療報酬改定の状況や、今年度から試行的に導 入された医療機器等への費用対効果評価等をご紹介したい。

〈略歴〉

平成 15 年 長崎大学医学部医学科 卒業

平成 15 年 国立災害医療センター研修医

平成 16 年 東京医療センター研修医

平成 17 年 厚生労働省老健局老人保健課 主查

平成 21 年 米国カリフォルニア大学ロサンゼルス校 (UCLA) 公衆衛生大学院 卒業

平成 22 年 厚生労働省大臣官房厚生科学課 国際健康危機管 理調整官

平成 22 年 東京医科歯科大学大学院医歯学総合研究科 博士 課程 卒業

平成 24 年 厚生労働省医政局医事課医師臨床研修専門官

平成 26 年 山口県健康福祉部健康増進課長

平成 27 年 山口県健康福祉部医療政策課長

平成 28 年 厚生労働省保険局医療課課長補佐
総会特別企画 07-2

腹腔鏡下肝切除の検証と普及 : 前向き 全例登録制度とエビデンスの創出

上尾中央総合病院外科

若林剛

腹腔鏡下肝切除は論理的優位性を持つ とされる。2014年に盛岡で行なわれ た第 2 回コンセンサス会議前に行った systematic reviewでは、世界中で 9,527 例の腹腔鏡下肝切除か 報告されていた。開腹と比較した総計 2900 例の meta-analysis によると、死亡率は高くなく、合併症・出血量・輸血率・入院 期間では腹腔鏡下肝切除の優位性が示された（Ann Surg 2016;263:761-77)。これまで、世界では 2つのランダム化比較 試験が行なわれ、その 1 つは詳細の報告が近々行われる予定で ある。本邦では、日本肝胆膵外科学会のプロジェクト研究とし

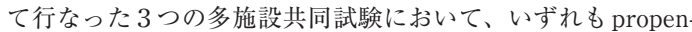
sity score matching 法を用いて肝細胞癌患者、大腸癌肝転移患 者、外側区域を除く 1 区域以上肝切除患者で、腹腔鏡下肝切除 が開腹肝切除と比較し短期成績が良好で長期成績が変わらない ことが示された。2010年に腹腔鏡下肝切除（部分切除、外側 区域切除）が先進医療から保険収載され、2014年には年間 2600 例を超えるの腹腔鏡下肝切除が行なわれるまでになった。 さらに、昨年 10 月から開始された前向き全例登録は、今年 6 月までに196施設が参加し 891 例が登録された。2016年 4 月か らは㛜密な施設基準と前向き全例登録を条件に、すべての腹腔 鏡下肝切除術式が保険収載された。今後は世界に類を見ない腹 胫鏡下肝切除データが本邦で集積され、さらなるエビデンスが 創出されると考える。

〈略歴〉

医学博士

現職：上尾中央総合病院 肝胆膵疾患先進治療センター長 診療部 外科長

1982年麖應義塾大学医学部卒業

1988-1990年 Research Fellow, Department of Surgery, Harvard Medical School and Massachusetts General Hospital, Boston

1993年慶應義塾大学医学部外科学教室助手

2001 年麖應義塾大学医学部外科学教室専任講師

2005年岩手医科大学第一外科教授

2006年外科系講座再編により第一外科講座より外科 学講座に名称変更 (小児外科部門を統合)

2015年卡尾中央総合病院外科診療顧問

2016年同肝胆膵疾患先進治療センター長、診療部 外科長

〈所属学会・資格等〉 現在に至る

日本外科学会 (専門医、指導医、認定医)

日本消化器外科学会（評議員、専門医、指導医、消化器がん治 療認定医)

日本肝胆膵外科学会（評議員、肝胆膵外科高度技能指導医）

日本内視鏡外科学会 (理事)

日本がん治療認定医機構（がん治療認定医、暫定教育医）

厚生労働省臨床修練指導医

肝臓内視鏡外科研究会（代表世話人）

日本肝癌研究会 (幹事) 


\section{総会特別企画 07-3}

Minimally Invasive Pancreatic Resection の検証と普及

九州大学臨床・腫瘍外科

中村雅史

Minimally Invasive Pancreatic Resection(MIPR)の分野では、後発である 腹腔鏡下膵体尾部切除術 (LDP) が腹

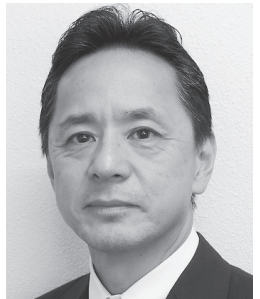

腔鏡下膵頭十二指腸切除術 (LPD) に先んじて普及して行き、 2011年からは保険収載もされることとなった。2015年には、 本邦より最大規模となる 2,000 人以上の患者データを用いた propensity score matching の比較研究が発表され、術後合併 症の領域においても LDPが良好な成績を示した。その後、 LDPはリンパ節郭清を必要とする腫瘍にまで適応が拡大され た。一方、先行して開始されたLPDであったが、世界的にも 普及速度は遅く、臨床成績に関する報告も少ない状況が続いて いる。このような状況下ではあるが、本年より保健収載される こととなった。しかしながら、その施設基準は㛜しく、全例登 録も義務付けられている。今後、LPDを安全に普及していく ためには、全例登録制度がもたらすデータの解析や、各施設間 の情報共有・公開が重要であると思われる。また、エビデンス 創出によるMIPRの普及のために、保険適用に関しての施設条 件とは関係なく、以前より準備中であった複数の学会・研究会 で運営する臨床研究としてのLPD, LDP術前全例登録システム も運用を開始した。今回、このような MIPR 領域におけるエビ デンスと普及の現状について発表する。

〈略歴〉

1988年 九州大学医学部卒、第一外科及び関連病院で外科臨床 研修

1992年 国立がんセンター中央病院肝胆膵外科レジデント

1995年 九州大学大学院入学、1999年学位取得し終了

1999年 ハーバード大学医学部 Cancer Biology Program リ サーチフェロー

2003年 九州大学 腫瘍制御学助手 (2005年准教授)、臨床 · 腫瘍外科診療従事 (肝胆膵外科部門)

2009年 九州大学臨床 - 腫痬外科 肝胆膵外科部門主任

2011 年 川崎医科大学消化器外科 主任教授

2015年 4 月より 九州大学臨床・腫瘍外科 教授

〈専門領域〉

肝胆膵外科、内視鏡外科、Cancer Biology

〈専門医等〉

日本肝胆膵外科学会高度技能指導医、日本内視鏡外科学会技術 認定医、日本外科学会専門医・指導医、日本消化器外科学会専 門医・指導医、日本がん治療認定医機構がん治療認定医・暫定 教育医

〈所属学会等〉

会 長 : 膵臓内視鏡外科研究会、事務局長 : 九州外科学会/九 州小児外科学会/九州内分泌外科学会

理 事：アジア外科学会、日本肝胆膵外科学会

評議員：日本外科学会 (代議員)、日本癌治療学会（代議員）、 日本内視鏡外科学会、日本膵臓学会、日本消化器外科学会、日 本臨床外科学会、日本バイオセラピイ学会、日本胆道学会、日 本膵切研究会 (運営委員)、肝臓内視鏡外科研究会 (世話人) 、 日本癌病態治療研究会（世話人）

〈編集委員〉

Journal of Hepatobiliary Pancreatic Sciences

Journal of Laparoendoscopic \& Advances Surgical Techniques

International Journal of Clinical Oncology

日本内視鏡外科学会雑誌

〈賞罰〉

ヒューマンフロンティア・サイエンスプログラム：ロングター ムフェローシップ (国際HFSP 推進機構、ストラスブルグ、仏)、 2000

The most outstanding research paper award in FEBS letter in 2002 (ヨーロッパ生化学会 (2003))

日本癌病態治療研究会 奨励研究 (2004))

第 113 回日本外科学会定期学術集会優秀ビデオ演題、日本外科

学会ビデオライブラリー最新手術シリーズ集録 (2013)

ベストドクター 2014-2017 選出
総会特別企画 07-4

呼吸器外科ロボット手術の現状と課

題：明らかになったこと、明らかにす

ベきこと

鳥取大学 胸部外科

中村廣繁, 谷口雄司, 荒木邦夫,

三和健

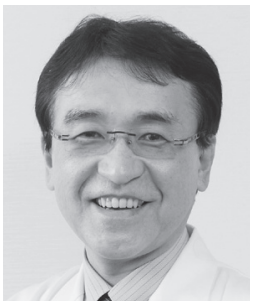

【はじめに】呼吸器外科のロボット手術（RATS）は保険適応 外で, 症例経験は進んでいない. 当科では, 2016年 8 月まで に肺癌 45 例 (転移 1 例), 縦隔疾患 40 例, 計 85 例に対して RATSを施行した。これまでに明らかになったこと, 今後明ら かにすべきことを検証して課題を考える.【肺癌】肺葉切除42例, 区域切除 2 例, 気管支形成を伴う右上葉切除 1 例. $\mathrm{CO}_{2}$ 送気に よる気胸併用 (completely portal robotic lobectomy:CPRL) で, 術野の安定性が向上し, 肺門処理や縦隔郭清なども容易になる. コンバートはなく, G 2 以上術後合併症は 8 例 $(17.8 \%)$, 特に G 3 以上呼吸器合併症は乳び胸の 1 例のみ (2.2\%) で, これは 同時期施行の開胸や胸腔鏡手術よりも有意に少ない。長期成績 は全例生存中, 再発 3 例で, 5 年無再発生存率 $88.0 \%$ である.【胸 腺疾患】重症筋無力症 15 例 (胸腺腫合併 10 例), 胸腺腫 12 例, 胸腺癌 2 例に対し, (拡大) 胸腺（胸腺腫）摘出術を施行. 胸 腔鏡手術が困難な大きな腫瘍 (最大径 $87 \mathrm{~mm}$ ), 浸潤型に対す る肺および心膜合併切除・心膜再建術も安全に施行できる.【ま とめ】当科のRATS成績は他の文献報告と同等で概ね満足で きる. 特に, 低い術後の呼吸器合併症の発生率が明らかになれ ば，それに伴うコストの軽減やQOL 向上など患者への恩恵が 証明できる。現在, 肺癌では先進医療Bを目指して, VATSを 参照データとした多施設共同試験の実施に向けて準備中であ る.

〈略歴〉

1984年 鳥取大学医学部卒業

1988年 鳥取大学大学院医学研究科 博士課程修了

1993年 鳥取大学医学部附属病院 第二外科助手

1998年 米国ワシントン州立大学 留学

1998年 鳥取大学医学部附属病院 第二外科講師

2001 年 国立米子病院 呼吸器外科医長

2005 年 鳥取大学医学部附属病院 胸部外科 科長/助教授

2013年 鳥取大学医学部 器官制御外科学講座 胸部外科学分野 教授

2015年 鳥取大学医学部 副学部長 (教務担当) 兼任

〈主要資格・所属学会〉 現在に至る

日本外科学会 (認定医·専門医 - 指導医)、日本胸部外科学会 (指 導医・評議員)、関西胸部外科学会（理事・評議員）、日本呼吸 器外科学会 (専門医·指導医 - 評議員)、日本内視鏡外科学会 (評 議員）、日本肺癌学会（評議員、中四国支部会幹事）、日本ロボ ツト外科学会 (理事) 
総会特別企画 $\quad 07-5$

画期的な医療技術の普及のために何が

必要か〜報道からの視点〜

朝日新聞社科学医療部

浅井文和

外科治療に新しい革新的な技術を導入 する場合、専門家による科学的な有効 性と安全性の評価は欠かせない。さら

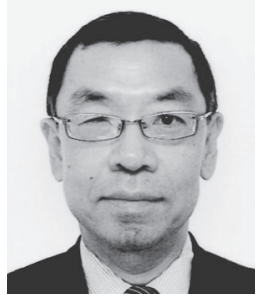

に、患者や一般市民の理解が得られないと、治療の普及は困難 に直面する。たとえば、内視鏡外科手術の年間症例数の推移を 見ると、内視鏡外科手術で深刻な医療事故が発生して、新聞・ テレビなどで大々的に報道された年次では実施症例数が減少す る傾向がある。報道する側を見ていると、医療事故の報道が医 療現場の問題点を社会に訴えて、制度改革を促し、安全対策を 促進する世論を喚起しょうとする側面はあるものの、何か問題 が起きた時だけに報道が集中して、継続的な情報提供に久けて いるという批判は免れない。革新的な医療技術には、患者の身 体的負担の軽減、安全性の向上、医療費の軽減などの点で患者 にとって利益をもたらす可能性があり、報道においては危機感 やリスクを惼るのではなく、客観的なデー夕を提示して、冷静 な評価をする必要である。一般国民の目からは、それぞれの医 療機関で実施されている医療技術の質が見えにくい。医療技術 の質を保つための研修・認証制度の現状や、医療機関のガバナ ンス体制に踏み込んで評価することで、国民にわかりやすい形 で医療の質の透明性を高めていく報道が求められている。

〈略歴〉

1981 年 京都大学理学部生物科学系卒業

1983年 京都大学教育学部教育心理学科卒業

1983年＼cjkstart朝日新聞社長崎支局記者

1990年＼cjkstart朝日新聞社東京本社科学部記者

2002 年 朝日新聞社大阪本社科学医療部次長

2004年 朝日新聞社東京本社科学医療部記者 現在に至る

\section{総会特別企画 $08-1$}

国家財政、医療の効率化と外科技術、 中医協委員の立場から JCHO東京山手メディカルセンター 万代恭嗣

中医協とは中央社会保険医療協議会 の略称で、健康保険制度や診療報酬の 改定などを審議する厚生労働相の諮問

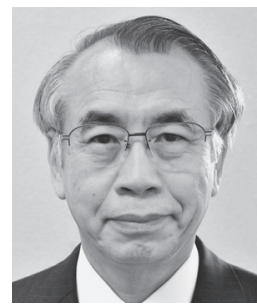
機関である。お金について直接議論し決定するため世間の注目 度は高い。しかし現在では、政府が決定する診療報酬改定率と 厚労省社会保障審議会が設定する改定の方針に基き、その範囲 で医療の発展等を組み入れて上記を決定する立場である。かつ ての全てを決めた機能からはかなり限定的役割となっている。 最終的な診療報酬点数は改定率によって大きく左右され、ほほ 全ての医療機関にとっての収入源に日本の財政状況が色濃く反 映されることとなる。中医協に扔ける財政面からの議論はこ れまでも当然行われていたが、将来の少子高齢化社会も睨んで、 さらに密度の濃い議論がなされることとなった。その代表例が 費用対効果専門部会の設置であり、現在は取り扱い条件を定め た上で既収載品から選定した医療機器 5 品目について、専門組 織による試行的導入の具体的な議論が開始されたところであ る。これ以外にも、保险医療材料等専門組織による特定保険医 療材料等に係る審議、医療技術評価分科会に扔ける主として学 会からの要望の審議結果に基づき、最終的には中医協総会で外 国平均価格の調整などこまかな費用面も考慮しつつ保険収載が 決定されている。これらの議論においては、効率性も考慮しつ つ医療の進歩の取入れを中心とし、医師の技術料を確保すると の立場としている。

\author{
〈略歴〉 \\ 1974年＼cjkstart東京大学医学部卒業 \\ 1977年東京大学医学部附属病院医員 \\ 1981年 文部教官助手 東京大学医学部外科学第二講座 \\ 1987年 社会保険中央総合病院外科部長 \\ 1989年 文部教官講師 東京大学医学部外科学第二講座 \\ 1995年 文部教官助教授 東京大学医学部外科学第二講座 \\ 1996年 社会保険中央総合病院副院長 \\ 2009年 社会保険中央総合病院病院長 \\ 2014年 独立行政法人地域医療機能推進機構 東京山手メデ \\ 〈専門〉 \\ イカルセンター院長 (組織移管により名称変更) \\ 消化器外科学、内視鏡外科学、超音波医学 \\ 〈学会・病院関係役員等〉 \\ 日本病院会常任理事、日本内視鏡外科学会監事、日本臨床外科 \\ 学会副会長等
}




\section{総会特別企画 08-2}

厚労省の立場からの外科医療技術の評

価

厚生労働省医政局経済課医療機器政策

室

金光一瑛

費用詨効果評価については、高額な医

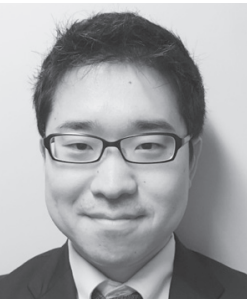

療技術の増加による医療保険財政への

影響についての懸念や、医療技術の保険収載や保険償還価格の

判断材料に費用対効果が重視されてこなかったことを背景とし

て議論の必要性が指摘され、平成 24 年 5 月に費用対効果評価 専門部会を創設し、議論を進めてきた。その後、平成 25 年 11 月に「議論の中間的な整理」をとりまとめた上で、平成 26 年 4 月から平成 27 年 5 月にかけて「具体例の検討」を実施して 制度設計に向けた課題の抽出を行い、平成27年 8 月 26 日には「試 行的導入に係る議論の中間報告」をとりまとめた。平成 28 年 度診療報酬改定においては、平成 27 年 12 月 16 日にとりまとめ られた「費用対効果評価の試行的導入について」に基づき、医 薬品や医療機器の保険適用の評価に際して費用対効果の観点が 試行的に導入されたところであり、更に、診療報酬改定に係る 附帯意見では、「医薬品・医療機器の評価の在り方に費用対効 果の観点を試行的に導入することを踏まえ、本格的な導入につ いて引き続き検討すること。あわせて、著しく高額な医療機器 を用いる医療技術の評価に際して費用対効果の観点を導入する 場合の考え方について検討すること。」とれたことから、今後、 中央社会保険医療協議会において検討が進められていくことと なる。これまでの議論を踏まえつつ、今後の考え方について概 説することとしたい。

〈略歴〉

厚生労働省医政局経済課 医療機器政策室 室長補佐

平成 18 年 3 月 東京大学医学部医学科卒

平成 18 年 4 月 三井記念病院（初期臨床研修）

平成 20 年 4 月 三井記念病院外科

平成 22 年 10 月 三井記念病院心臟血管外科 医員

平成 24 年 4 月 厚生労働省入省 健康局疾病対策課 課長補 佐

平成 26 年 4 月 保険局医療課包括化推進専門官

平成 26 年 10 月 同医療技術評価推進室長補佐

平成 28 年 4 月 医政局経済課医療機器政策室長補佐

現在に至る
総会特別企画 08-3

医療技術の費用対効果の評価手法と課

\section{題}

国立保健医療課科学院 医療・福祉サ

\section{ービス研究部}

福田敬

医療サービスの効率性を考える際に

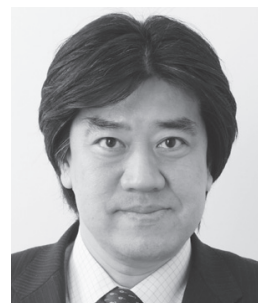

重要な点は費用対効果の考え方であ

る。単に費用が少ない医療を効率的とはいわない。より高い効 果を得るのに見合った投資であれば、むしろ積極的に導入すべ きである。追加的な成果を得るためにどの程度の費用が必要か を表す指標が増分費用効果比 (Incremental Cost Effectiveness Ratio: ICER）である。医療サービスの費用効果分析で用い る効果の指標は疾患や介入方法によって適切な尺度を設定す る。近年、単に延命だけを目的とするのではなくその間の Quality of Life (QOL) が重要であるという指摘から、治療の成 果を表す指標として質調整生存年 (Quality Adjusted Life Year: QALY）を用いる研究が増えてきている。QALYは様々 な疾患や介入等に対して共通に用いることが可能な指標である ことから、費用対効果評価を政策に応用している国では多く用 いられている。日本では、中央社会保険医療協議会において 平成 28 年度から医薬品・医療機器についての費用対効果評価 の試行的導入が開始されており、今後は著しく高額な医療機器 を用いる医療技術の評価などについても検討される見込みであ る。費用対効果の評価結果を政策に応用するためには、評価 手法をある程度統一する必要があり、日本でも費用対効果の分 析ガイドラインが作成されている。

〈略歴〉

国立保健医療科学院 医療・福祉サービス研究部 部長 $\langle$ 学歴・職歴〉

平成 2 年 3 月

7 年 3 月

7 年 4 月

東京大学医学部保健学科卒業

東京大学大学院医学系研究科保健学専攻博士 課程修了

13 年 4 月 東京大学医学部 保健管理学教室 助手

18 年 4 月 東京大学大学院薬学系研究科 医薬経済学 客員助教授

18 年 4 月 客療経済研究機構 研究部長（兼任 平成 20 年 3 月)

19年 4 月 東京大学大学院医学系研究科 臨床疫学・経 済学分野 准教授

23 年 11 月 国立保健医療科学院 研究情報支援研究セン ター 上席主任研究官

26 年 4 月 国立保健医療科学院 統括研究官

27 年 4 月 国立保健医療科学院医療・福祉サービス研 〈役職等〉 究部 部長

厚生労働省 保険医療専門審査員（医療技術評価分科会委員） 厚生労働省 先進医療会議構成員

中央社会保険医療協議会 費用対効果評価専門部会 参考人 〈研究分野〉

医療経済、医療管理 
総会特別企画 08-4

外保連の立場からの外科医療技術の評 価

聖マリアンナ医科大学 小览外科 11 ,

外科系学会社会保険委員会連合 ${ }^{2}$

川瀬弘一1,2), 岩中督2), 瀬戸泰之 ${ }^{2)}$,

水沼仁孝2)，矢永勝彦 ${ }^{2)}$, 山口俊晴2)

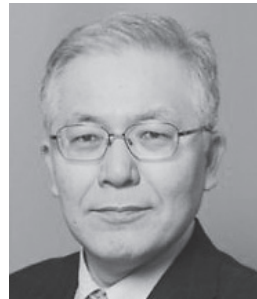

外科系学会社会保険委員会連合（以下、外保連）は手術手技 の適正な評価のもとに手術報酬の合理的な原価計算を試みて、 その結果を手術試案として公表している。その科学的根拠とな る評価軸は人件費、医療材料費である。人件費は手術の技術度、 手術協力者数、所要時間の $3 つ の$ 要素から算出、医療材料費は 各領域学会が実施した 50 例以上の実態調査結果に基づいてい る。昨年発刊された手術試案 8.3 版には 3,386 件の全術式に人件 費、医療材料費の費用計及びその詳細が揭載されている。

手術試案 8.2 版では、 2012 年に行った実態調査の結果を反映 して試案の手術時間等を補正した結果、平成 26 年度改定では 試案の人件費が下方修正された 81 術式で、実際の診療報酬の 手術料が減点になった。厚生労働省が外保連手術試案を診療報 酬点数の相対評価として用いていることが明らかになった点は 大きな前進であったが、絶対評価としての評価ではなく、外保 連試案点数を修正すると診療報酬は増点もあれば、減点もあり 得るということが明らかになった。外保連では手術委員会内に 「医療技術の新しい評価軸検討ワーキンググループ」を立ち上 げ、それぞれの手術の背景を様々な視点から再検討し、手術試 案8.3版に「手術の新しい評価軸」を公表した。その結果、緊 急帝王切開術など一部の手術で復活・増点が得られたが、この 評価軸は試案の科学的根拠を曖昧にしてしまう可能性もあり、 今後も検討が必要である。

\section{〈略歴〉}

1983年：東京医科大学医学部卒業

1987年：埼玉医科大学大学院（第2外科学専攻）博士課程修了

1987 年 : 埼玉医科大学病院助手 (第 2 外科)

1990年：国立小児病院レジデント (外科)

1992年：埼玉医科大学助手 (第 2 外科)

1995年：埼玉医科大学短期大学講師 (看護学科) 埼玉医科大学非常勤講師 (小览外科) 兼務

2000年：埼玉医科大学短期大学助教授 (看護学科)

2002年：聖マリアンナ医科大学講師 (小児外科)

2004年：聖マリアンナ医科大学横浜市西部病院副部長

2011 年 : 聖マリアンナ医科大学病院経営管理室室長

2015年：聖マリアンナ医科大学外科学 (小児外科) 病院教授 現在に至る

\section{総会特別企画 $08-5$}

消化器外科医 現場からの声〜消化器 外科医の素朴な疑問〜

東邦大学 一般・消化器外科

島田英昭

【緒言】消化器外科手術手技の価格に 関して以下の論点を考察する。【手術 手技の適正価格】手術工程の積算価格 で算出される手術費用は社会が受け入れられる価格であるか 器械・縫合糸メーカーが価格競争する仕組みを導入する必要が あるのではないか。【良性疾患と悪性疾患の手術価格】良性疾 患に対する手術は生涯医療費総額を大幅に軽減できる。たとえ ば、胃縮小手術によって 2 型糖尿病治療は劇的に変化する可能 性がある。悪性疾患に対する手術は質調整生存年の概念で経費 を比較することがかなり難しい。【同一手技は同一価格】手術 の完成形が同一であればその過程に関わらず同一価格が望まし い。腸管手縫い吻合の価格は、器械吻合と同等の価格と寻る心 きではないか。【手術手技の比較試験】手技は、薬剂と異なり 完全に同一ではないことから比較試験の実施時期や実施組織に よって結果が異なる可能性が高い。重要な手技については、複 数回の検証が必要かもしれない。悪性疾患手術では予後の優越 性を証明できれば質調整生存年の概念で付加価值を算出する。 予後非劣性かつ低侵襲を証明できれば医療費軽減効果を算出す る。真に有用な手技・器械は保険収載前でも普及する。【ロボ ット手術と腹腔鏡下手術】 開腹手術と比較した低侵襲性の経済 的利益を検証し、さらに腹腔鏡下手術と比較してロボット手術 の優越性を検証する。仮に非劣性かつ外科医にとって「低侵襲」 であれば人件費が削減できるのか

〈略歴〉

生年月日 1959 年12月 26 日 56 歳

現 職 東邦大学医学部外科学講座 一般 - 消化器外科学分 野 教授 東邦大学大学院外科学講座 教授

学歴及び職歴〉 東邦大学大学院臨床腫瘍学講座 教授

1978年 3 月 20 日：東京教育大学附属高等学校卒業

1984年 3 月 23 日：千葉大学医学部卒業

1991 年 3 月 25 日：千葉大学大学院医学研究科博士課程（外科 系) 修了

1991年 6 月 1 日：研究員（米国マサチューセッツ総合病院 ハーバード大学 外科)

2002 年 7 月 1 日：文部科学教官 千葉大学講師大学院医学研 究院 (先端応用外科学)

2008年 1 月 1 日：千葉県がんセンター 消化器外科 主任医

2009 年 10 月 1 日：東邦大学医学部外科学講座 一般 ·消化器 外科学分野教授 (大学院教授併任)

2009年 10 月 1 日：東邦大学医療センター大森病院 消化器セ ンター外科教授併任

2009年11月 1 日：千葉大学疾患プロテオミクス寄附研究部門 客員教授兼任（2015年 3 月まで）

2012年 10 月 1 日：東邦大学大学院臨床腫瘍学講座教授併任

2016年 10 月 5 日: 第 36 回日本分子腫湯マーカー研究会当番世 話人

診療・研究領域：食道・胃外科、固形癌の分子診断・分子治療 〈公的研究費・研究組織など〉

• 21 世紀COE コアメンバー

·JST独創的シーズ展開事業 代表研究者

〈学会役職・学術雑誌編集委員等〉

- 理事・評議員・世話人など：日本外科学会,日本消化器外科

学会, 日本癌学会, 日本臨床外科学会, 日本食道学会 (理事)

日本胃癌学会, 日本免疫治療研究会 (理事)、日本分子腫痬 マーカー研究会、外科分子細胞治療研究会（世話人・代表幹 事)、胃外科術後障害研究会 etc

- Editor \& Associate editor: Ann Gastronenterological Surgery, Esophagus, Gastric Cancer, Ann Thoracic Cardiovascular Surgery, Digestive Surgery, Surgery Today, J Hepato-Biliary-Pancreatic Sciences

- Editorial Bord: Int J Clin Oncology, J Gastroenterology. World J Gastroenterology, J Surgical Oncology etc.

〈受賞歴：癌の分子診断・分子治療に関する研究に対して〉

$\cdot 2003$ 年 なのはなベンチャーコンペ最優秀賞

・2003年 ちばぎんひまわり賞最優秀賞

-2016年 日本消化器外科学会学会賞 2016年JSGC Science of the Year (学術部門)

〈論文等〉

- Publications $=388$, Total citations $=6829$, $\mathrm{h}-\mathrm{index}=46$, i10-in $\operatorname{dex}=152$ 


\section{総会特別企画 08-6}

費用対効果からみた Transcatheter aortic valve implantation(TAVI) の

有用性

大阪大学 低侵襲循環器医療学 倉谷徹

2013年に大動脈弁狭窄症（AS）に対するTAVI

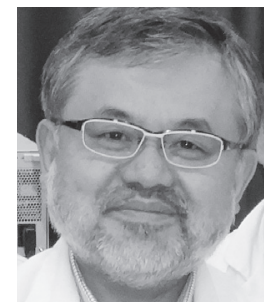
が保険償還されてから、TAVIはその低侵襲性

から症例数を激增させている。更に海外ではその適応を低りスク症例に拡大し つつある。しかしTAVIデバイス自体のコストは極めて高額であり、更に適応 を拡大するためには費用対効果を検討する必要がある。

そこで我々は、当院における外科的弁置換 (SAVR) と TAVI症例の費用対効 果を検討した。その結果、保険請求額は有意にTAVI群が高值であった。その 内訳は、TAVIにおけるデバイス費が著しくSAVRと比較して高額であったが、 入院費を含め手術外費用はTAVI群が低值であった。またTAVIに揖いてはリ スクが高くなってもその費用に変化はないが、SAVRにおいてはEUROscore12 以上では費用が高值となった。つまり低りスクではSAVRの費用対効 果からの有用性が更に惹起される。

またTAVI症例に上る経験值効果を費用対効果の面から検討するため、前期後 期に分けて之の費用対効果を算出。当院の結果ではデバイス以外の手術 保険請求点は有意に低下したが (手術手技技術は優位に向上した)、全保険請 求点では変化なかった。つまりデバイス費が極めて大きな割合を占めることが 明確となった。

以上によりTAVIのデバイス費用は非常に高額であり、デバイス費が低下しな い限り、すべての患者に対してSAVRに代わってTAVIが導入されることは極 めて費用対効果から考えて保険上、著しく不利益であることが示唆された。

\section{〈略歴〉}

昭和34年（1959年）11月 29 日生

〈学歴〉

昭和 61 年 3 月

平成 2 年 3 月

職歴

平成 2 年 4 月 6 月

神戸大学医学部医学科 卒業 大阪大学大学院医学系研究科博士課程 修了

平成 2 年 7 月 平成 4 年 12 月

平成 5 年 1 月 12 月 大阪大学大学

平成 6 年 1 月 平成 7 年 2 月

日本生命済生会付属日生病院外科 医員

大阪府立病院 (現大阪府立急性期・総合医療 センター) 心臟血管外科医員

平成 7 年 3 月 6 月

Children's Memorial Hospital (Chicago, USA) Research fellow

平成 7 年 7 月〜平成 8 月 6 月
平成 8 年 7 月〜平成 18 年 9 月 大阪大学大学院医学系研究科 外科学第一教 室 研究生

国立只病院 心臟血管外科 医員

大阪府立急性期・総合医療センター 心葴血 管外科 参事

平成 18 年 10 月 平成 19 年 3 月 大阪大学大学院医学系研究科 心臟血管外科 平成 19 年 4 月 平成 21 年 9 月 助教

平成 19 年 4 月 平成 21 年 9 月 大阪大学大学院医学系研究科 先進心血管治 平成 21 年 10 月 平成 24 年 3 月 $\begin{aligned} & \text { 療学阪大学大学院医学系研究科 心臟血管外科 } \\ & \text { 学 准教授 }\end{aligned}$

平成 22 年 4 月 平成 24 年 3 月 大阪大学医学部附属病院 病院教授

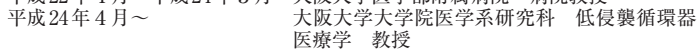

〈所属学会等〉

The European Association for Cardio-Thoracic Surgery(EACTS) Active Member

The Asian Society for Cardiovascular and Thoracic Surgery(ASCVS) Active Member

日本外科学会

日本胸部外科学会 評議員

日本心臓血管外科学会 国際会員・評議員

日本血管外科学会 評議員·外保連委員

日本循環器学会

日本人工臓器学会

日本脈管学会

日本心血管インターベンション治療学会

大動脈ステントグラフト研究会 幹事・世話人

岡山大学医学部非常勤講師 $(\mathrm{H} 22.4 .1 \sim \mathrm{H} 26.3 .31)$

北海道大学病院 客員臨床医師 (H22.5 H23.3)

ステントグラフトの力学試験方法に関するJIS 原案作成委員会＼cjkstart委員（H21.10

$\sim \mathrm{H} 22.3$

〈资格・免許等〉

昭和 61 年 5 月

平成 2 年 3 月

平成 4 年 12 月

平成 18 年 1 月

平成 18 年 12 月

平成 19 年 7 月

平成 20 年 9 月

平成 20 年 9 月

医師免許証

医学博士の学位授与

外科認定医取得

心臟血管外科専門医取得

外科専門医取得

腹部ステントグラフト実施医基準 基礎経験審査合格

胸部ステントグラフト実施医基隻＼cjkstart基礎経験審查合格

胸部ステントグラフト指導医（GORE TAG Thoracic Endprosthesis)

平成 20 年 12 月 腹部ステントグラフト指導医（Powerlink Stentgraft Sys-

tem

平成 21 年 6 月 胸部ステントグラフト指導医（TALENTTM Thoracic Stent

平成 22 年 1 月 脈管専門医取得

平成 22 年 10 月 心臟血管外科修練指導者認定

平成 23 年 6 月 胸部ステントグラフト指導医（Zenith TX 2 TAA Endovascular Graft)

平成 23 年 11 月 腹部ステントグラフト指導医（ENDURANT AAA STENT

平成 24 年 6 GRAFT SYSTEM)

平成 24 年 6 月 胸部ステントグラフト指導医（VALIANT Captivia）

平成 25 年 5 月 胸部ステントグラフト指導医 (Relay Plus)
総会特別企画 09-1、コメンテーター

初めての手術〜 1 年間のオストメイト

生活から私が得たもの

アナウンサー

中井美穂

〈略歴〉

ロサンジェルス生まれ。 87 年 95年、 フジテレビアナウンサーとして活躍。

97 年から「世界陸上」(TBS) のメインキャスターを務める。 現在、「タカラッ゙カ・カフェブレーク」(TOKYO MXテレビ)、 「楽しいラジオ」(FM東京)、舞台「スジナシBLITZシアター」 他に出演。

その他、演劇コラムの執筆やクラシックコンサートのナビゲー ター・朗読、2013年より読売演劇大賞選考委員を務める。

また、CNJ (キャンサーネットジャパン) に賛同し、2011年以 降コーディネーターや講演を務めている。

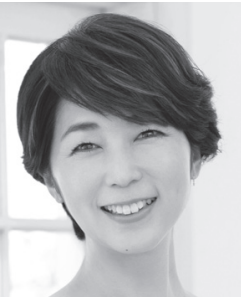


総会特別企画 09-2

手術療法へのがん患者の立場からの期 待

一般社団法人全国がん患者団体連合会 天野慎介

2006 年に成立したがん対策基本法に 基づき、国のがん対策推進基本計画に より各地にがん診療連携拠点病院など

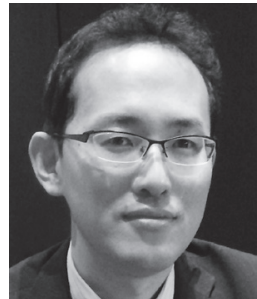

が整備されてきた。基本計画では「様々ながんの病態に応じ、 手術療法、放射線療法、化学療法、さらにこれらを組み合わせ た集学的治療がそれぞれを専門的に行う医師の連携の下実施さ れていくことが求められている」とされ、加えてがん医療の進 歩に伴い、治療成績の向上や侵襲の少ない手術などが拡がりつ つある。一方で、同じく基本計画では「今も手術療法ががん医 療の中心であることに変わりはないが、外科医の人員不足が危 惧され、外科医の育成や業務の軽減が早急に改善すべき課題と なっている」とされ、腹腔鏡手術による患者の死亡事例など、 手術療法に打ける医療過誤などに対する関心も高まっている。 NCD (National Clinical Database) などを活用し、手術療法の 可視化などを進めることで、手術療法の更なる向上が期待され る。

\section{〈略歴〉}

1973 年東京都生まれ、慶應義塾大学商学部卒。2000年に悪性 リンパ腫を発症。2 度の再発を経験し、化学療法、放射線療法、 自家末梢血幹細胞移植などを受ける。自身の経験をもとにがん 患者支援活動に関わるようになり、現在、一般社団法人全国が ん患者団体連合会理事長、一般社団法人グループ・ネクサス. ジャパン理事長、厚生労働省厚生科学審議会がん登録部会委員、 厚生労働省がん診療提供体制のあり方に関する検討会構成員、 文部科学省がんプロフェッショナル養成推進委員会委員などを 務める。

\section{総会特別企画 09-3}

こんな外科医と仕事がしたい 昭和大学 保健医療学研究科 梅田恵

外科医療の技術革新は、留まることな く発展を続けている。「病気を抱える ひとの命を守りたい」「人々の生活の 質を高めたい」などの、社会への貢献

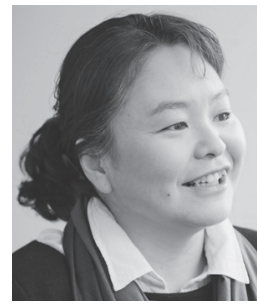

拡大をめざした一人一人の医師の努力の集大成であることはま ちがいない。がん医療を取り巻く社会の状況も大きな発展の ときを迎えている。我が国においては2007年にがん策基本法 施行され、さまざまな施策が行われてきた。がん医療の均てん 化が重点課題であり、基準をクリアしたがん医療に取り組む施 設が提示され、多くの情報が患者や家族に届けられるようにな ってきた。また、見えにくく、よくわからなかったがん治療内 容や戦略は、EBMへの取り組みの進歩とともに、さまざまな ガイドラインの公表も行われ、患者や家族だけでなくコメデイ カルも治療への理解が深まり、治療選択や治療後の生活管理な ど協力できる体制も整いつつある。また、患者間のつながり もとても重要な要素となってきており、患者アドボカシー (Advocacy) 活動が活発化してきている。病院内や医療者だけ で医療が完結することは難しくなってきた。患者が主体的に治 療に参加し、多くのリソースを活用できる時代をむかえ、あら ためて外科医の役割や、更なる外科医療の技術の発展を可能と する、共に仕事をしたいと思う外科医の姿について考えてみた いと思う。

〈略歴〉

〈現職〉

昭和大学院保健医療学部研究科 がん看護専門看護師コース 教授

昭和大学病院看護部 がん看護専門看護師

1992 年 3 月 聖路加看護大学編入学 卒業

1994年 4 月～2006年 9 月 昭和大学病院

1999年 3 月 聖路加看護大学院 がん看護専門看護師コース 修了

2000年 10 月 日本看護協会 がん看護専門看護師認定

2013年 3 月 聖路加看護大学院 博士後期課程 修了 2014 年 11 月 現職

〈著書〉

がん看護の日常にある倫理（2016）、医学書院、[編著］

骨転移の知識とケア (2015)、医学書院、[編著］

専門看護師の思考と実践 (2015)、医学書院、[編著］

がん患者のペインマネジメント（2007）、日本看護協会出版会、 [共著］

緩和ケア (2011)、南江堂、[編著］

〈役員〉

日本がん看護学会 理事

死の臨床研究会世話人 国際交流委員

日本緩和医療学会 評議委員

〈社会活動〉

認定NPO法人 キャンサーネットジャパン理事

NPO法人 マギーズ東京メンバー

NPO 法人 友愛ホーム理事 


\section{総会特別企画 09-4}

da Vinciにて鏡視下低位前方切除を受 けた 1 消化器外科医の提言

豊田地域医療センター

宮川秀一

昨年 8 月肚門から $10 \mathrm{~cm}$ の直腸に 2 型 のガンが見つかった.手術を受ける際 に考えたことは，「根治を期待できる

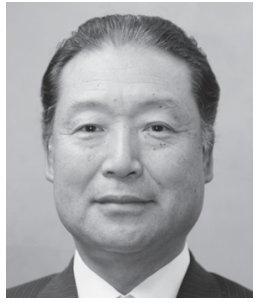

病変か, 期待できるならどんな手術療法が良いか,その手術の合 併症の頻度はどうか,そして術後の運動制限を最小で短期間に したい」ということであった.そこで手術創の小さい大腸の内 視鏡下手術で根治性のある手術が可能かどうか, 同門の後輩医 師に相談した。「3 群リンパ節まで廓清が可能であること, 一般 の腹腔鏡下 (保険適応) より da Vinci手術（実費）の方がやり 易い.縫合不全などの大きな合併症は 71 例中 1 例である」との ことでda Vinciにて低位前方切除を受けた.10日ほどで退院し， 1 ケ月後にはゴルフも出来た.排便習慣の変化はあるが現状に は満足している.小生が思う消化器外科医が持つべき診療技能 は, 腹部救急疾患への対応, 消化器ガンでは診断能力, 正確な進 展度診断と病態把握,術式の適応と立案,根治性の追求,チーム の手術成績の開示と正確なインフォームドコンセント,立案し た根治手術の完遂, 偶発症や合併症への対応, 補助療法など術後 のフォローアップ,診療ガイドラインの利用,消化器内科医なと 他科の医師との協力関係の構築, 同僚外科医や外科関連スタッ フとのチーム医療の遂行,後輩外科医の指導と育成などが求め られる.da Vinci手術を受けた 1 消化器外科医の所感を述べさ せていただく

〈略歴〉

1976年 3 月 名古屋大学医学部 卒業

1976年 4月 厚生農業協同組合連合会安城更生病院 研修医

1977 年 4 月 厚生農業協同組合連合会安城更生病院外科医 員

1979年 12 月 名古屋 (現; 藤田) 保健衛生大学医学部外科学助 手

1984年 3 月 医学博士 (名古屋大学)

1986年 6 月 藤田保健衛生大学 医学部外科学講師

1997年 4 月 藤田保健衛生大学 医学部外科学助教授

2001年 8 月 藤田保健衛生大学 医学部胆膵外科講座教授

2003 年 11 月 藤田保健衛生大学病院 副院長 (救急担当)

2006 年 4 月 藤田保健衛生大学統合外科運営委員長, 外科系 課程主任

2006年 12 月 藤田保健衛生大学外科系教授会議長

2012 年 3 月 藤田保健衛生大学 医学部胆膵外科講座教授 退職

2012 年 4 月 藤田保健衛生大学 名誉教授

公益財団法人 豊田地域医療センター 常務理 事・院長

2014年 6 月 公益財団法人 豊田地域医療センター 理事長

現在に至る

〈公職歴等〉

2009年 7 月

日本消化器外科学会第 66 回総会会長（2011年 7 月開催

2011年 8 月～保険医療専門審査員、診断群分類見直し作業 班肝胆膵外科班長 (厚労省保健局より委嘱)

2012 年 5 月 一般社団法人日本専門医制機構 専門研修プ ログラム研修施設評価・認定部門委員 専門医認定・更新部門委員

2015年 4 月～一般社団法人日本医療安全調査機構 総合調 整医
総会特別企画 $10-1$

医療安全からみた外科医のプロフェッ ショナリズム一来院から退院まで様々 なリスクを意識して一 鹿児島大学消化器 · 乳腺甲状腺外科 夏越祥次, 内門泰斗

外科は侵襲を伴う治療を行うため, 常に

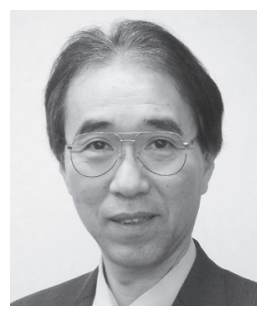
リスクを伴っているといっても過言では

ない. 来院時に患者と家族に接した時から Informed consent (IC) を 含め様々なリスクを意識することが重要と考える。教室内では朝夕の 主治医グループ（臓器別）による回診での患者の状態を共有, 総回診 時にはグループで問題となっている術前・術後状態のチェックを行 う. 病棟医長, 看護師長を交えた患者・家族を含めた病棟内問題点や 医師と看護師の意思疎通の確認など情報の共有を行っている. 朝の力 ンファレンスでは, 主治医グループが各症例の術前問題点を列挙し, 他の臓器グループを交えた討論を行い, 様々な観点から意見を出して チェックする。術式を決定する上で腫瘍側因子は重要であるが, 術前 合併症を含めた患者側因子を詳細に分析して，術後に起こりうる合併 症を含めて検討することがリスクの減少につながると考えている，術 後報告では術前問題点との相違や, 術式の確認を行い, 適正であった かを議論している。院内の他科で報告されるインシデントレポート を参考にして，当科でも起こりうる事象に関してはカンファレンスで 情報を共有している.インシデントレポートを積極的に提出させるよ うに努め, 患者安全の確保を図るとともに, 隠ぺいが起こらないよう に透明性を求めるようにしている。来院から退院まで様々なリスクを 意識して, 独断的にならずお互いが綿密にチェックしていくことが肝 要と思われる.

〈略歴〉

昭和 56 年 3 月 広島大学医学部卒業 6 月 鹿児島大学医学部第 1 外科入局

昭和 58 年 4 月～昭和 61 年 3 月 出張病院にて研修

昭和 61 年 4 月 昭和 63 年 3 月 部内研究生

昭和 63 年 4 月～平成 2 年 9 月 出張病院勤務

平成 2 年 10 月 鹿児島大学医学部第 1 外科助手

平成 8 年 4 月〜平成 9 年 6 月 ドイッ・ミュンヘン工科大学 (Prof. Siewert) 留学

平成 11 年 7 月 鹿児島大学医学部第 1 外科講師

平成 16 年 3 月 鹿児島大学医歯学総合研究科腫瘍制御学・消化器外 科学准教授

平成 21 年 1 月 鹿児島大学医歯学総合研究科 消化器 - 乳腺甲状腺外 科学教授、現在に至る

平成 27 年 4 月鹿児島大学附属病院 副病院長（医療安全担当）

〈学会活動〉

日本外科学会

代議員, 臨床研究推進委員会委員, 都道府県安全管理責任者

日本消化器外科学会

理事. (2010 2016), 評議員, 広報委員会委員長, 専門医制度委員 会委員，資格認定委員会委員，医療安全委員会委員，将来構想委員 会委員, 外科関連学会協議会代表委員, 評議員選出委員会地区委員, 学術集会運営委員会委員, 学術委員会委員, 学会創立 50 周年記念 事業準備委員会委員

日本食道学会

監事 (2016 ), 理事 (2009 2015), 評議員, 用語委員会副委員長, 会誌編集委員会委員, 専門医制度委員会委員, 食道専門医認定医認 定部会委員, 食道専門医カリキュラム設定部会委員会, NCD 部会 委員, 医療安全委員会委員長

日本胃癌学会

評議員, 胃癌取扱い規約委員会委員, 会則委員, 選挙管理委員会委 員

日本癌治療学会

代議員, 将来計画委員会委員

日本臨床外科学会

評議員

日本消化器病学会

九州支部 評議員, 学術研究助成金選考委員会委員

日本消化器癌発生学会

理事, 評議員, あり方委員会委員長

日本リンパ学会

常任理事, 編集委員

日本胸部外科学会

評議員

日本がん転移学会

理事, 評議員

日本大腸肛門病学会九州支部

幹事, 評議員

日本胸部外科学会九州地方会

評議員

〈専門分野〉

消化器. 乳腺甲状腺癌の外科治療と術前診断, 消化器 - 乳腺甲状腺癌 の悪性度に関する分子生物学的・遺伝子学的研究, 癌の微小転移, 消 化器・乳腺甲状腺癌化学療法に関する研究 
総会特別企画 $10-2$

肝胆膵外科手術を安全におこなうため に必要なあたりまえのこと

聖マリアンナ医科大学消化器・一般外 科

大坪毅人

肝胆膵外科手術の死亡率は減少傾向に

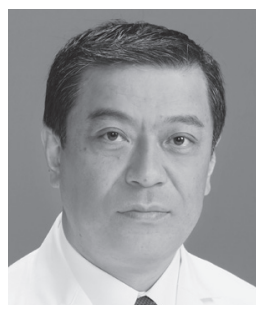
あるが未だ死亡率の高い手術がある。

それは左三区域切除、肝膵同時切除、肝移植レシピエント、胆 道再建を伴う肝切除、右三区域切除である。肝移植はレシピエ ントの全身状態が悪いことが多く同じ组上では議論できないた め肝移植以外でみると、死亡率の高い手術とは肝切除量の大き い手術、あるいは肝切除に胆道消化菅・膵消化管吻合などを付 加した手術であるといえる。肝胆膵外科手術後の死亡率が高い 原因は手術そのものの難易度が高いほか、術後の肝不全、膵液 瘦、感染など重篤になりやすい合併症の起こる頻度が高いこと が挙げられる。一つの医療事故の背後に29の軽微な事故があり、 その背後に 300 のヒアリハットがあるという法則があるが、術 後の死亡例においてこの法則が当てはまる事例はわずかである と考える。手術に関係するインシデント、アクシデント事例を いくら検討しても死亡率の滅少には結びうかないと思う。こう いった手術を安全に行うためには、あたりまえのことではある が障害肝や黄疸肝に抢ける肝切除の適応限界を厳格にするこ と。膵胆道癌においては腫瘍の進展度診断を正確に行うこと。 外科医は常日頃、手術手技の向上に精進し、自らの技量の限界 を自覚することに尽きると思う。孫子曰く“彼を知り、己を知 れば百戦して殆うからず”である。この見極めこそが肝胆膵外 科医に必要なプロフェッショナリズムではないだろうか。

〈略歴〉

生年月日：1959（S34）年 7月 13日 57歳

1986年 3 月 聖マリアンナ医科大学医学部卒業

1986年 6 月 医師国家試験合格 医籍登録 第 301472 号

1986 年 6 月 東京女子医科大学消化器外科医療練士研修生

1992年 3 月 同修了

1992年 4 月 東京女子医科大学消化器外科助手

2003年 8 月 東京女子医科大学消化器外科講師

2004 年 10 月 聖マリアンナ医科大学外科学消化器外科部門教授

2005 年 4 月 聖マリアンナ医科大学外科学消化器 ・ 一般外科部 門教授

2007 年 4 月 聖マリアンナ医科大学付属病院 中央手術部部長 兼任

2014年 4 月＼cjkstart聖マリアンナ医科大学病院副院長兼任 聖マリアンナ医科大学病院臨床研修センター長兼 任

現在に至る

\section{〈認定資格〉}

日本外科学会専門医、指導医

日本消化器外科学会専門医、指導医

日本肝胆膵外科学会高度技能指導医

臨床研修指導医

日本医師会認定産業医

Instructor of Advanced Trauma Operative Management
総会特別企画 $10-3$

医療の質向上のための有害事象報告制 度の確立と医療安全文化の醸成

自治医科大学さいたま医療センター 医療安全・渉外対策部

遠山信幸

【はじめに】自院で発生した有害事象

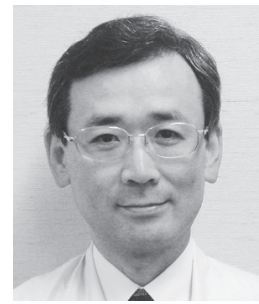
(インシデント) 報告は医療安全の基 本であり、報告数はProfessional Autonomyの指標の一つであ る。昨年度の当院の全報告数は 24,125 件、医師報告は 1,081 件 だった。重要な報告は個々の事例を深く掘り下げた上で対策を 講じる必要がある。当院では重大事例や警鐘的事例に対し、事 例検討会や外科系 M\&Mカンファランスを開催、原因究明と再 発予防策の検討を行っている。事例検討会】医師報告に基づき、 センター長と副センター長、医療安全管理室メンバー合議の上、 開催が決定される他科横断的な症例検討会 (Peer review) で ある。2003年より開始し現在まで 268 回開催し、内容は年 2 回 の報告会で全職員に対しfeedbackしている。【M\&Mカンファ ランス】外科系 12 診療科全体による診療内容の相互チェック と情報共有のために 2004 年から開始し、現在まで 135 回開催さ れた。月 1 回の定期開催で毎回 2 診療科が担当となり、自科で の術後 M\&M 症例や他科横断的な手術症例などを提示検討する とともに、麻酔・ICUからの連絡や新任医師の紹介なども兼ね た外科系全体の情報共有の場ともなっている。【まとめ】医療 の透明性・公正性を高め、質向上と安全の確保に最大限の努力 を払うことは医療従事者の使命であり、術後合併症を含めた有 害事象報告とそれに基づく質改善活動は診療行為の一環であ る。外科医個々の努力とともに、病院組織としての対応・院内 報告文化の醸成も重要である。

\section{〈略歴〉 \\ 〈学歴・職歴〉}

1983 年 3 月 自治医科大学医学部卒業

1994年 4 月 自治医科大学附属さいたま医療センター総合医 学講座 II (一般・消化器外科) 助手

2001 年 4 月 同 講師

2005 年 10 月 同 准教授 兼 医療安全管理室長

2013年11月 同 教授

2014年 4 月 同 センター長補佐

2016年 4 月 同 副センター長 兼 医療安全・渉外対策部

現在に至る

〈専門〉

医療安全学、一般・消化器外科学（肝胆膵外科、ヘルニア外科）

〈資格〉

医療の質・安全学会 代議員 監事

日本外科学会：専門医、指導医

日本消化器病学会 : 専門医、指導医、評議員

日本消化器外科学会：専門医、指導医

日本臨床外科学会：評議員

日本肝胆膵外科学会：高度技能指導医、評議員

日本ヘルニア学会 : 評議員

日本外科系連合学会：評議員

日本医師会：認定産業医

日本温泉気候物理医学会：認定温泉療法医

日本がん治療認定医機構暫定教育医

日本医療メディエーター協会：認定医療メディエーター

さいたま市医療安全推進協議会副会長 


\section{総会特別企画 $10-4$}

プロフェッショナリズムと外科医と医

療安全

東京大学大学院法学政治学研究科 樋口範雄

一部の医師の間で、プロフェッショ ナリズムについての議論がなされてい る。しかし、それぞれが考えるプロフ

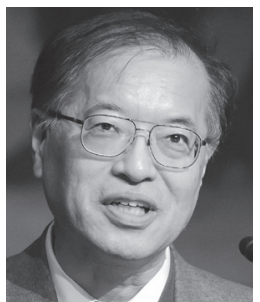
エッショナリズムの意義も主張の目的も必ずしも一致しない。 おそらくプロフェッショナリズムとカタカナ書きの英語のまま になっているのはそれが原因の 1 つである。本報告では、一 般に、専門家に通底するプロフェッショナルであることの要件 を整理したうえで、特に外科医について問題となる状況を $2 つ$ 提示し、それについて検討を加える。 まず、専門家であると いえるためには、次の $5 つ の$ 要件を満たす必要がある。第 1 に、 参入に相当の知的訓練を要すること。第 2 に、実務において複 雑な判断を求められ、それに対応できること。第 3 に、依頼人 との間に情報格差があり、第 4 に、依頼人は専門家を評価でき ず盲目的に頼らざるを得ないので、専門家には依頼人に対する 忠実義務が課されること。最後に、第 5 点として、専門家個人 および専門家団体には公益に配慮した自己規律が求められるこ とである。このような点に配慮しつつ、外科医が直面する 2 つの状況について考察する。1つは、当該手技に相当のリスク があるが、患者家族がそれに同意している場面。もう1つは、 当該手技にリスクが少なく、利益が相当に見込めるのに、患者 家族が同意しない場面である。

〈略歴〉

1974年＼cjkstart東京大学法学部卒業

1974年 東京大学法学部助手

1978年＼cjkstart学習院大学法学部専任講師

1979年 同助教授

1985年 同教授

1992年 東京大学大学院法学政治学研究科教授 現在に至る

主要著作に、医療の個人情報とセキュリティ（第 2 版 2005 年・ 有斐閣)、生命倫理と法ケーススタディ（第 2 版 2012 年・有斐 閣)、医療と法を考える一救急車と正義（2007年・有斐閣）、続 · 医療と法を考える一終末期医療ガイドライン (2008年・有斐 閣)、超高齢社会の法律、何が問題なのか（2015年・朝日新聞 出版)。

\section{総会特別企画 11-基調講演}

National Clinical Databaseの分析から 見えてくる新たな医療のあり方

慶應義塾大学 医療政策・管理学教 室 $^{1)}$, 東京大学 医療品質評価学講 座 $^{2}$, 国立国際医療研究センター 国 際保健政策・マネジメント研究科 ${ }^{3)}$ 宮田裕章1.2.3)

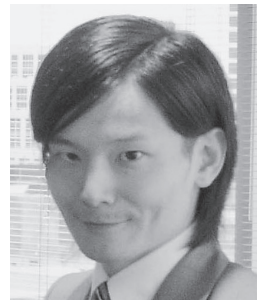

日本は医療・福祉を含む社会システムにおいて，大きな転換点 を迎えている。かつて高度経済成長をもたらした，「多数の労 働人口で少数の高齢者層を支える」人口構成を前提とした社会 保障制度を基礎に，世界トップランクに位置する長寿国となっ た。しかし今後, 世界でも経験のないスピードで高齢化が進み, さらに人口減少と産業成長の鈍化に伴い, 社会システム自体が, 従来の枠組みの延長線上でのマイナーチェンジだけでは，成立 することが難しくなってくるだろう。一方で他の先進国やアジ ア諸国も日本と同様の問題に直面することが予想されるため, 日本の動向に大きな関心を寄せている。日本の課題は将来のグ ローバルな課題にもつながるため, 日本が世界に先駆けて解決 策を示す役割が期待されている。ただし、こうした課題への 挑戦は，単にネガティブな側面ばかりではない。例えば「団塊 の世代」が医療・福祉を必要とする超高齢社会の初期段階にお いては, 公的・私的を問わず多くの資金が医療福祉分野に投入 されるため, 雇用の創出, 人々の暮らしを支える技術やシステ ムのイノベーションなど，次の日本を支える新しい活力を生む 可能性がある。本報告ではNational Clinical Databaseの分析 を軸にした様々なエビデンスを踏まえ、人口減少社会における 新たな医療のあり方を展望する。

〈略歴〉

H13 (2001) 3 東京大学医学部健康科学 · 看護学科卒業

H15 (2003) 3 東京大学大学院医学系研究科健康科学・看護 学専攻修了

H17（2005） 3 同専攻 博士課程中途退学（論文博士取得）

H17 (2005) 4 早稲田大学人間科学学術員 助手

H18 (2006) 8 東京大学大学院医学系研究科医療品質評価学 講座 助教

H21（2009）４東京大学大学院医学系研究科医療品質評価学 講座 准教授

H26（2014）4 東京大学大学院医学系研究科医療品質評価学 講座 教授 (2015年 5 月より非常勤)

H27（2015） 5 慶應義塾大学医学部医療政策・管理学教室 教授

・厚生労働省 参与（2015年 9 月～)

- 国立国際医療研究センター 国際保健政策・医療システム研 究科科長 (非常勤: 2016年10月～)

・日本医師会 客員研究員 (2016年 6 月 )

. 厚生労働省 保健医療 2035 策定懇談会構成員

・厚生労働省 保健医療分野におけるICT活用推進懇談会 構 成員

・厚生労働省 データヘルス時代の質の高い医療の実現に向け た有識者検討会 構成員

・大阪府 2025 年万博基本構想検討会議メンバー

・福岡市福岡市健康先進都市戦略策定会議メンバー

・静岡県「社会健康医学」基本構想検討委員会メンバー 
総会特別企画 $11-1$

NCDでみえてきたこと 呼吸器外科 専門領域一肺癌手術死亡のリスク解析 自治医科大学 呼吸器外科 ${ }^{11}$, 東京医 科大学 呼吸器外科 2 , 東北医科薬科 大学 呼吸器外科3), 東京大学 呼吸 器外科 ${ }^{4)}$, 杏林大学 呼吸器外科 5), 名古屋大学 呼吸器外科 ${ }^{6}$, 獨協医科

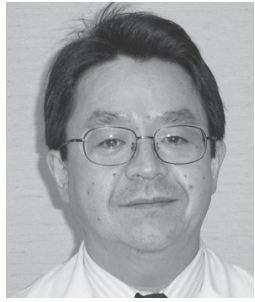
大学 呼吸器外科7), 鹿児島大学 呼吸器外科 ${ }^{8}$, 岡山大学 呼吸器外科 ${ }^{9}$, 東北大学 呼吸器外科 ${ }^{10)}$, 筑波大学 呼吸器外 科 ${ }^{11)}$, 大阪大学 呼吸器外科 ${ }^{12)}$, 横浜市立大学 外科 ${ }^{13)}$, 静岡 市立病院 胸部外科 ${ }^{14)}$

遠藤俊輔 ${ }^{1)}$, 池田徳彦 ${ }^{2)}$, 近藤丘 ${ }^{3)}$, 中島淳 ${ }^{4)}$, 近藤晴彦 ${ }^{5)}$,

横井香平 ${ }^{6)}$, 千田雅之 ${ }^{7}$, 佐藤雅美 ${ }^{8}$, 豊岡伸一 ${ }^{9}$, 岡田克典 ${ }^{10)}$, 佐藤幸夫 ${ }^{11)}$ ，吉田浩一 ${ }^{2)}$ ，奥村明之進 ${ }^{12)}$ ，益田宗孝 ${ }^{13)}$,

千原幸司14)

呼吸器外科専門領域は、2011年当初の基本項目に加え、2014 年から詳細な手術・術前後の情報を登録するシステムへとグレ ードを上げるとともに、インセンテイブとして呼吸器外科専門 医申請と胸部外科学術調查自動出力システムをリンクさせ悉皆 性と整合性を維持させた。2014年呼吸器外科専門領域の手術 を登録した施設は約 1000 施設で、胸部外科学術調查 800 施設よ り多く、登録数も 4000 例以上多い約 85000 例であった。肺癌手 術は実数の 95\%以上の約 39000 例が登録され、世界でも類を見 ない年次登録症例数となった。Web 監査システムにより手術 記録 563 例の入力データの整合性をチェックすると年齢・性 別・術式などは $97 \%$ 以上と高い整合率であった。2014年のデ ータベースにより肺癌の手術死亡リスク解析を行うと患者因子 として男性、60歳以上、PS ・ 肺活量 · 間質性肺炎・虚血性心 疾患・喫煙歴があがり、腫瘍学的因子として腫瘍径・cStgae 3 期以上・肺尖部浸潤肺癌・非腺癌があがった。また外科的因子 として肺全摘・複合肺葉切除・右下葉切除・胸壁合併切除があ がった。Poor risk例での手術死亡リスク解析 (C-index0.856) を客観的に評価できるようになった。(結語）肺癌病期決定へ の重要な情報を世界へ発信してきた日本が肺癌手術死亡リスク 解析に関する新たなBenchmarkを築いた。（文献）Endo S. Development of an annually updated Japanese national clinical database for chest surgery. GTCS 2016.

〈略歴〉

1959年 9 月 1 日生まれ

1984年筑波大学医学専門学群卒業 同病院外科レジデン 卜

1989年 カナダ マギール大学実験医学研究部門研究員

1992年自治医科大学胸部外科助手

1998年宇都宮社会保険病院呼吸器外科科長

2000 年 自治医科大学呼吸器外科講師

2004年＼cjkstart自治医科大学呼吸器外科助教授

2005年自治医科大学附属さいたま医療センター呼吸器外 科助教授

2008 年 4 月 自治医科大学附属さいたま医療センター呼吸器外 科教授

2008 年 10 月 自治医科大学外科学講座呼吸器外科学部門教授

2015年 4 月 自治医科大学外科学講座主任教授

\section{総会特別企画 11-2}

$\mathrm{NCD}$ 乳癌登録の現状と展望

東海大学 乳腺・ 内分泌外科 11 , 日本 乳癌学会登録委員会 2

徳田裕 ${ }^{1,2}$

1975年より乳癌研究会の事業として 開始された乳癌登録は, 2004年には, web 登録システムに移行し, 2011年ま

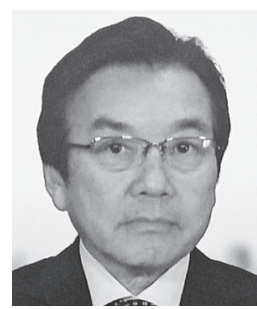
での総登録症例数は 255,519 例であった. 2011 年次登録症例数 は48,563例であり，2012年から NCD に参加することにより 2012 年次登録症例数は, 72,473 例と飛躍的に増加した. さらに, 2004 年からの過去データ 238,140例がNCDに移行された。デー 夕移行症例を含め, 5 年毎の再発, 一次治療内容, および死亡/ 死亡原因についての予後登録を実施している。2004年次登録 症例数は, 14,805例であったが, 予後登録症例数は, 7,241例, 48.9\%であった。 そこで，予後登録はリアルタイムに入力可能 なシステムとした。また，施設ごとに予後登録が必要な症例の web 上でのアラートや報告率の表示により, 入力率の向上を図 っている.

乳癌診療ガイドラインを軸にQuality Indicatorを選択し，その 実施率を測定している. 全国平均との対比も含め自施設の実施 率をフィードバックするとともに，常時修正入力を可能にする ことで，入力の正確性を高めつつ，医療水準の均てん化を推進 している.さらに，標準治療を遵守した場合の予後を症例ごと にリアルタイムに予測することが可能であり，日本版予後解析 ツールの実装を目指している。

〈略歴〉

1978年

1983年

慶応義塾大学医学部卒業

東海大学医学部外科学教室助手

1985-1987年＼cjkstart米国カリフォルニア州立大学ロサンゼルス校 (UCLA)

腫湯外科学教室

1991年東海大学医学部外科学教室講師

1998年東海大学医学部外科学教室助教授

2004年東海大学医学部外科学系乳腺・内分泌外科学教 授

現在に至る

2009年東海大学医学部付属病院オンコロジーセンター 長

現在に至る

東海大学医学部付属病院がん診療連携拠点病院 運営委員長

〈学会活動〉

現在に至る

日本外科学会指導医 - 専門医, 日本乳癌学会 - 評議員 - 専門医, 日本臨床腫瘍学会・協議員, 日本癌学会評議員, 日本臨床外科 学会評議員

1995年

Member of the American Association for Cancer Research

1996年 Member of the American Society of Clinical Oncology

2011年 Member of the European Society for Medical Oncology

2012年 Associate editor of the Cancer Science 
NCDから見えてくる消化器外科医療 神戸大学 食道胃腸外科学 ${ }^{11}$, 日本消 化器外科学会データベース委員会委員 長 $^{2)}$, 日本消化器外科学会データベー ス委員会アドバイザー ${ }^{3)}$, 日本消化器 外科学会理事長 ${ }^{4}$

掛地吉弘 ${ }^{1,2)}$, 後藤満一 ${ }^{3)}$, 今野弘之 ${ }^{3)}$,

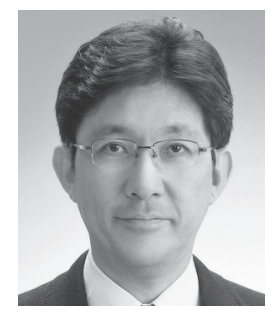

宮田裕章 ${ }^{3)}$, 瀬戸泰之 ${ }^{4)}$

消化器外科領域では米国の American College of Surgeons National Surgical Quality Improvement Program (ACS-NSQIP) との連携のもと、医療水準評価対象術式（主たる8術式）の 2011 年登録症例約 12 万例を用い、8 術式のリスクモデルを構 築した。このモデルを用いたNCD Feedback 機能を適宜リリ ースし、2015年 9 月には 8 術式のリアルタイムフィードバック、 Risk Calculator ( 手術を受ける患者さんの術後 30 日死亡予測発 生率，手術関連死亡予測発生率を計算する)、施設診療科の患 者背景とパフォーマンスの全国比較、パフォーマンス指標およ び合併症発生率の閲覧などのデー夕活用が可能となっている。 臨床現場における様々な課題にALL JAPANのデータとして 応えるべく、NCDのデータを利活用した臨床研究を2013年よ り開始した。その多くは、集積されたデー夕を用いた後ろ向き 調查研究であるが、日本内視鏡外科学会からの「腹腥鏡下胃切 除術の安全性に関する検討 - National Clinical Databaseによ る前向き調查研究」と題する前向き研究も含まれている。全て の施設からのデータによる後ろ向き研究と、施設を絞った前向 き研究から、わが国の消化器外科医療の現状が解り、標準化と 集約化の方向性も見えてくることを期待したい。NCDを活用 することで、消化器外科診療の改善に向けた課題を同定し，合 併症発生率の低下, 入院期間の短縮など, 医療の質の向上や医 療コストの低下に寄与することが期待される。

〈略歴〉

1987年 九州大学医学部卒業

1991年 国立病院九州がんセンター医師（消化器部外科）

1994年 米国 Harvard Medical School, Dana-Farber Cancer Institute, Research fellow

1996年 九州大学医学部助手 (外科学第二講座)

1999年 佐賀県立病院好生館（外科医長）

2002 年 九州大学医学部附属病院腫瘍センター講師

2003年 九州大学医学部附属病院先端医工学診療部助教授

2005年 九州大学大学院消化器・総合外科助教授

2012 年 神戸大学大学院外科学講座食道胃腸外科学分野教授

日本外科学会 (代議員)、日本消化器外科学会 (理事 - 評議員)、 日本癌学会 (評議員)、日本癌治療学会 (評議員)、日本食道学 会 (理事・評議員)、日本胃癌学会 (理事・評議員)、日本内視 鏡外科学会 (評議員)、日本臨床外科学会、日本臨床腫瘍学会 (評 議員)、日本大腸肛門病学会、大腸癌研究会（世話人）

Fellow of American College of Surgeons (FACS)

American Society for Clinical Oncology (ASCO)

American Association for Cancer Research (AACR) 